\title{
DISSING LEARNING DISABILITIES
}

by

Richa Sud

Hon. BSc., McMaster University, 2012

BSW, Lakehead University, 2013

\author{
An MRP \\ presented to Ryerson University \\ in partial fulfillment of the \\ requirements for the degree of \\ Master of Social Work \\ in the Program of \\ Social Work
}

Toronto, Ontario, Canada, 2014

(C) Richa Sud 2014 


\section{AUTHOR'S DECLARATION FOR ELECTRONIC SUBMISSION OF A MRP}

I hereby declare that I am the sole author of this MRP. This is a true copy of the MRP, including any required final revisions.

I authorize Ryerson University to lend this MRP to other institutions or individuals for the purpose of scholarly research.

I further authorize Ryerson University to reproduce this MRP by photocopying or by other means, in total or in part, at the request of other institutions or individuals for the purpose of scholarly research.

I understand that my MRP may be made electronically available to the public. 


\author{
ABSTRACT \\ Dissing Learning Disabilities \\ Master of Social Work, 2014 \\ Richa Sud \\ Program of Social Work, \\ Ryerson University
}

This qualitative research study explores the experiences of post-secondary students with Learning Disabilities (LDs). Using phenomenology, semi-structured interviews were conducted with four university students from Southern Ontario. The study discusses the strengths, challenges, commonalities and differences between the students' academic experiences through which they have derived current academic success. Data analysis draws from Critical Theory of Education, Social Model of Disability and Goffman's analysis of Stigma. The findings in this study provide insight into the classroom experiences of the students with LDs in elementary, middle and high schools. Further, they help understand ways adapted by students to navigate the education system through each of their varied experiences. This paper will conclude with implications and suggestions for social work professionals working with students who have LDs.

Key Words: Learning Disabilities, Learning Difficulties, Learning Differences, LDs, Education and Social Work, Students with LDs, Successful students with LDs. 


\section{ACKNOWLEDGEMENTS}

Firstly, I would like to thank all the participants who shared their stories for this project. Their generous contribution is the major foundation of this research. I am sincerely thankful to them for sharing a part of their life with me.

Secondly, I am thankful to Dr. Susan Silver, my Research Supervisor who guided me through the research journey. I deeply believe that I am fortunate to have been supervised by Dr. Silver. Her scholarly guidance, upbeat attitude and confidence in my abilities collectively stimulated my learning. I believe that her continuous encouragement, support and feedback were essential to the development and implementation of this project.

Also, I am thankful to Dr. Judith Sandys, who was my Second Reader for this research paper. With her contribution, I was better able to shape the research project through her refined academic critique of my work. I am thankful to her for spending her time and energy to correct my research paper.

Further, I am grateful to the MSW professors who have taught me to apply AntiOppressive approach in practice and research: Dr. Purnima George, Dr. Samantha Wehbi, Dr. Kristen Smith and Dr. Gordon Pon.

I am also very thankful to my family and friends who offered their never-ending support to help me complete this research project and my MSW degree. While welcoming my discussions about the project, they offered sincere advice, motivation and assistance to assist me with the research project. Thank you for believing in me! 


\section{DEDICATION}

I would like to dedicate this research project to:

My Mum: Neena Sood

\&

My Dad: Anil Sud

Dear Mum and Dad,

The two of you have always inspired me deeply with your approach to life.

You have always been committed to provide our family with a good and happy life.

I deeply admire your strong, loving and positive attitude that is a key to our perseverance. You have both spent years to support and guide me unceasingly with your love, care and wisdom. Thank you for always being there for me.

I am blessed to have you as my parents, and to have a caring younger brother: Rajat.

Love,

Richa 


\section{TABLE OF CONTENTS}

Chapter 1: Introduction

Page 1

Chapter 2: Literature Review

Page 8

Chapter 3: Theoretical Frameworks

Page 14

Chapter 4: Methodology

Page 22

Chapter 5: Findings

Page 28

Chapter 6: Analysis

Page 58

Chapter 7: Conclusion

Page 67

Appendices

Page 72

Reference List

Page 81 


\section{LIST OF APPENDICES}

$\begin{array}{lll}\text { Appendix A Study Flyer } & \text { Page } 72\end{array}$

$\begin{array}{lll}\text { Appendix B Email Recruitment Script } & \text { Page } 73\end{array}$

$\begin{array}{lll}\text { Appendix C Telephone Script } & \text { Page } 74\end{array}$

$\begin{array}{lll}\text { Appendix D } & \text { Consent Form } & \text { Page } 76\end{array}$

$\begin{array}{lll}\text { Appendix E Interview Guide } & \text { Page } 80\end{array}$ 


\section{CHAPTER 1. INTRODUCTION}

In today's fast pacing world, education is considered to be essential for maintaining a strong career profile that can support a decent lifestyle. Martin (2012) identifies that the Ontario's secondary school curriculum for students aged 5-18 attempts to shape students as "workers under construction" (p.263). A direct relationship between education and health of the economy can be comprehended where "corporatist/careerist mantras" (p.263) that establish social positions, have been swamping classrooms and shaping educational practices (Martin, 2012; Wotherspoon, 1998). However, often times the mainstream notion of what constitutes a normative learning style to support the neoliberal agenda could be considered as a fallacy for those who may be labeled as having a "Learning Disability". The literature suggests that although the intelligence of a child with a Learning Disability (LD) may compare favourably with that of his peers, his performance level does not (Learning disabilities: The hidden handicap", 1993). Thus, in order to match the performance level of their peers, students with a LD require creative or modified techniques to learn and apply their knowledge.

Learning Disabilities (LDs) are defined by Learning Disabilities Association of Canada (LDAC) as "specific neurological disorders that affect the way a person stores, understands, retrieves and/or communicates information" (Learning Disabilities Association of Canada, n.d.). This definition is based on the dominant Medical Model of Disability. However, this paper takes an alternative perspective to define LDs by using the Social Model of Disability. By applying this model, LDs are comprehended to be differences in learning styles which lead to negative social reaction or structural barriers for an individual (Oliver, 1990).

Individuals with Learning Disabilities (LDs) have been identified to be at a high risk because they are commonly impacted by issues across the life span such as: underachievement, 
high drop-out rates, low self-esteem, underemployment, job difficulties and prolonged dependence on others (Cory, 2005; McNulty, 2003; McDonald et al., 2007; Kistner et al., 1987). Moreover, statistics note that individuals with disabilities are at least one-and-a-half times more likely than others of the same age and gender to become victims of bullying or assault (Sobsey, 1994; in Sherry, 2010). Thus, it is critical to assess the experiences of individuals with LDs through an anti-oppressive approach to serve social justice.

The label of LDs derogates the personality and self-esteem of the person, while it also interferes with their participation in societal matters as citizens (Stubblefield, 2007). Some of the areas in which individuals labeled as "disabled" suffer from are: deprivation of the opportunity to challenge themselves developmentally, ability to apply their skills and talents to contribute to the society and of being able to enjoy full protection of their rights (Stubblefield, 2007). Further, Lee (1999) describes the link between disability and poverty; whereby in order to eradicate poverty it is significant to provide opportunities for disabled individuals to enjoy equal rights as their nondisabled counterparts. Prince (2009) also recognizes that disabilities correlate with the maldistribution of resources in the form of income, employment, housing and other material resources. The voice of individuals with disabilities is thus marginalized in processes of citizenship such as: elections, policy development and decision making processes (Prince, 2009).

In this research project, I focus on the experiences of students with LDs who have been able to overcome societal challenges and are currently pursuing post-secondary education. My interest in this area of research originates from my experience as a service provider in the Learning Disabilities Association of Peel Region (LDAPR). Through my involvement with individuals with LDs, I became aware of the challenges imposed by the mainstream society on my clients. I found that education, employment, housing and economic status were areas that 
seemed to be interlinked for individuals with LDs. Since education is considered to be one of the founding instruments for individuals to attain employment and housing (Martin, 2012), I chose to focus my research on the educational aspect of LDs. Further, being a student myself I am able to view the challenges that could be present for students with different learning needs in the mainstream education system. Thus, I decided to explore the experiences of students with LDs who have been successful at surpassing any societal barriers that strained their progress in the education system. I hope that through this research, I am able to present the experiences of students with LDs as legitimate knowledge within the academia. This would serve the function of doing social justice for the community and for my research participants (Strega, 2005).

\section{Historical Context}

The term "learning disability" conveys stigma and assumptions about the characteristics of the student. It produces a negative social image of being not just "different" in learning style but being "disabled" from the normative learning style (Connor, 2013). This, negative association further seeps into students with LDs and could lead to their lack of self-esteem and feeling of worthlessness (McNulty, 2003; Watson and Larson, 2006).

Reid and Valle (2004) argue that, rather than being a personal characteristic, disability is a societal characteristic. It reflects socio-political influences on forming discourses and thus recognizes the power held by the elites in the society to socially engage in the production of the “norm" (Reid \& Valle, 2004). Further, learning disabilities are in constant flux as they are constructed from the social view, beliefs, needs and actions of people collectively (Reid \& Valle, 2004). The underlying ideology of Reid and Valle's (2004) claim is founded on the field of eugenics in North America. Franklin (1994; in Connor, 2013) reflects that labels such as "backwards", "mentally deficient", "illiterate", "incorrigible" and "socially maladjusted" 
developed in public schools in the $20^{\text {th }}$ century. These labels were generally associated with working class, poor and immigrant children (Carrier, 1986; in Connor, 2013). The term "learning disability" originated in 1960s to provide a privilege for white, middle class children that were assumed to be "normal" (Connor, 2013; Reid \& Valle, 2004).

\section{The Canadian Education System}

In Canada, the earliest form of education was included in the daily life practices of the First Nations people to cater to the practical needs of family, clan or community (Wotherspoon, 1998). The first form of formal schooling was hereafter set by missionaries and religious orders that aimed to replace "Indigenous lifestyles and knowledge with European concepts of morality and consciousness" (p.48). Wotherspoon (1998) confirms that although the intentions to introduce European forms of education may have been masked by the virtue of being noble towards Indigenous peoples, the education system was crafted on the opinion that Europeans were morally and intellectually superior to the Indians. The current objectives of the education system as Wotherspoon (1998) describes is to provide formal learning opportunities through the curriculum and to reshape the identities of the students in order to contribute towards the process of Canadian nation-building. In late 1960s, schooling started to be recognized as an "ideological state apparatus" that contributed towards the maintenance of unequal power relations among classes (Wotherspoon, 1998).

The British North America Act of 1867 which is now known as the Constitution Act provides Canadian provinces with the legal jurisdiction over all levels of education (Kirby, 2010; Sattler, 2012). Neoliberal values have influenced education governance reforms that have been introduced in Ontario between 1993 and 2009 (Sattler, 2012). This can be viewed through practices that reflect a neoliberal agenda such as: (i) measures to reduce education expenditures 
by amalgamating school boards and centralizing funding, (ii) increase accountability through new provincial curriculum which directs towards increasing the effectiveness of school boards by clarifying roles and responsibilities within a neoliberal accountability paradigm, (iii) outcomes-based education, (iv) standardized testing where the Education Quality and Accountability Office (EQAO) was created and is currently in practice to conduct standardized testing for students in Grades 3, 6, 9, and 11.

A student who is unable to complete age appropriate tasks risks being placed into the category of being "disabled" (Connor, 2013; Reid \& Valle, 2004). The concept of testing school children and assigning age appropriate tasks for grade levels tends to be an organizing factor in school settings (Baker, 2002). Stubblefield (2007) recognizes that the mode of testing and categorizing individuals changes with time. In the Ontario school system EQAO tests are conducted for students to "measure student achievement in reading, writing and mathematics in relation to Ontario Curriculum expectations (About EQAO)". The results of the tests are used to evaluate the accountability and a gauge of the quality of the education system. The EQAO website states that the test results act as a catalyst to increase success of Ontario students by providing evidence about learning. The EQAO testing system can be viewed as a prominent example of the neoliberal influence on education. The annual report prepared by EQAO highlights the agency's activities, accomplishments and financial performance for the preceding year to the government, education community, parents and the public. Students, parents and teachers are pushed to achieve target scores which would help establish progress within the education sector. Salutin (2012) describes that standardized tests like EQAO invade the classroom; where they attempt to instruct teachers on ways to teach and force them to teach for the sole purpose of testing. The concept of using standardized tests such as EQAO in the 
education system could therefore be considered as a marginalizing process for students with LDs.

Stubblefield (2007) states that individuals holding power in society have the ability to determine the testing procedures which are modes through which students could be marginalized. In a school system, the categorization of students as "disabled" and "non-disabled" acts as a social hierarchy model that places the disabled children into special education classroom settings (Connor, 2013). An educational disability such as a LD is used as a tool in the $21^{\text {st }}$ century to identify students who may present themselves outside of the mainstream norms of child development, or are at the risk of failing at school (Baker, 2002). Thus, it resembles the eugenics movement that was employed to identify individuals who did not belong to a superior class, race or had qualities such as of being feebleminded (Baker, 2002; Connor, 2013; Stubblefield, 2007).

Further categorization of students in the formal education system occurs through the mode of 'streaming' or placing students into different programs based on their aptitude, ability, or special interests and needs (Wotherspoon, 1998). Pedagogical justifications for streaming are held by the beliefs that by grouping students of similar backgrounds, interests and abilities, learning process is more effective and efficient (Wotherspoon, 1998). Through this system, students may be streamed into either a vocational or academic stream, which determines their eligibility of taking courses at the remedial or advanced streams within basic subject areas (Wotherspoon, 1998). Wotherspoon (1998) writes that students who belong to working class families or visible minority groups are more likely to be placed in the lower vocational streams; whereas students from privileged households are more likely to be placed into the academic stream, and have access to resources in schools that are better equipped to yield success (Curtis, 
Livingstone, and Smaller, 1992). The process of streaming is of critical importance as it could shape their academic career choices, such as pursuing post-secondary education and relevant career opportunities available to them (Wotherspoon, 1998). Further, it derogates the student's self- esteem due to explicit categorization of students where they begin to recognize their status within the classroom, becoming aware of where the system has placed them (Wotherspoon, 1998).

Heydon and Iannacci (2006) determine that there are limited spaces in the education sector to question the meaning of being abled or disabled in the school system, and to question the curricula for students with disabilities. The combination of the biomedical approach and educational policies disables the entire school populations, while consequently it imposes a reductionist literacy curriculum for the students (Heydon and Iannacci, 2006). Further, in contrast to the normative testing, Delpit (2003) addresses that it is important for the education system and its stakeholders to quit from attempting to determine the capacity of the students. It is important for educators to be convinced of the students' inherent intellectual capability, humanity, and spiritual character (Delpit, 2003). In regards to student access in Canadian Education system, Kirby (2010) describes that it is one of the most dominant policy areas in Canadian higher education where governments provide targeted funding to special disadvantaged and underrepresented groups including students with disabilities. However, it can be derived from the literature that segregation continues to be implemented on students based on their ability within classrooms (Connor, 2013; Reid \& Valle, 2004).

In the current research project I aim to explore and analyse the experiences of students with LDs by applying Critical Theory in Education (CTE). Further, I will also apply the theories of stigma and social model of disability as frameworks to inform my research project. 


\section{CHAPTER 2. LITERATURE REVIEW}

The literature review of the research topic led to the inclusion of various research articles in the current analysis. The following key themes were encountered in the review:

\section{Self-Perception}

Scholarship on LDs identifies that LDs negatively impact perception of self by influencing personality, emotional life and self-esteem (McNulty, 2003). Members of stigmatized groups internalize public stigma which includes prejudice, stereotypes and discrimination (Watson \& Larson, 2006). They also suffer a loss of self-esteem and self-efficacy (Watson \& Larson, 2006).

Labeling and stigma shape perceptions of one's self (Barga, 1996.) LD also detracts from positive gender expectations and exacerbates negative ones (McDonald, Keys \& Balcazar, 2007). LD further conveys the feeling of worthlessness, and lower opinions about one's cognitive and physical abilities (McDonald et al., 2007; Kistner, Haskett, White \& Robbins, 1987). Shessel \& Reiff (1999) describe the imposter phenomenon that inputs the feeling of devaluing one's own credibility along with a consistent fear of the discovery of the real self. The literature identifies that emotional health; anxiety, depression, stress and suicide rates are higher for individuals with LDs (Shessel \& Reiff, 1999 \& Gallegos, Langley \& Villegas, 2012).

Leinchtentritt \& Snechtman (2010) identify that from a very young age children with LDs experience emotional and social difficulties. Emotional health and development issues are also identified in individuals with LDs (Arthur, 2003). Anxiety, depression, frustration and suicide rates were speculated through heightened state of fear and stress on health on individuals with LDs (Gallegos, Langley \& Villegas, 2012; Heiman \& Precel, 2003; Shessel \& Reiff, 1999). 
Finally, McNulty (2003) identifies that childhood insecurity for individuals with LDs continues into adulthood.

Individuals with LDs often find themselves being excluded from mainstream sociospaces such as pubs/cafés and public transport where they are exposed to bullying and intimidating behaviour (Hall, 2004). Social isolation and perception lead to feeling of being different in individuals with LDs (McNulty, 2003 \& Shessel \& Reiff, 1999). In school settings Fredrickson \& Furnham (2001) noted that children with LDs were more likely to be rejected by their peers and less likely to be popular. Cory (2005) identifies that some of the consequences for individuals who reveal their LDs could include: being teased about their LDs at a young age, and being aware of the stereotypes that are brought by revealing the disability; such as laziness, incompetency or craziness. Mishna (2003) states that children and youth with LDs experience a higher risk of being bullied in comparison to their peers without LDs. Further, gatekeeping and negative attitudes of teaching staff in school setting act as an exclusionary force to maintain status quo (Barga, 1996 \& Reed, Lewis and Lund-Lucas, 2006).

\section{Coping Strategies}

Individuals are marginalized when they fail to conform to hegemonic normalcy that often belongs to mainstream views (Sherry, 2010). Since the nature of LDs is not physically visible, it allows the opportunity for individuals with LDs to pass deliberately or by default where they are able to conceal their LD. This provides them with the opportunity to escape the labeling and stigma associated with LDs, thereby bringing the "anonymity of privilege" (p. 774; in Sherry, 2010) to their unmarked bodies (Walker, 2001). Thus, the individuals may be able to escape the stigma, but would also be denied the accommodations that may help them learn and perform better at school and work (Denhart, 2008; Hinshaw, 2007). As a result, the concealment of LDs 
influences the overall lifestyle of individuals by compromising their access to good and meaningful education and employment. Individuals who would disclose their LD at educational settings may not disclose or seek accommodations for their LD at workplace due to fear of stigma (Madaus, 2008).

Lightner, Kipps-Vaughn, Schulte and Trice (2012) recognized that students chose to disclose and use accessibility services in university when they were under academic crises. It was observed that students who sought services late reported that limited knowledge about the services acted as a barrier for them (Lightner et al., 2012). Further, other reasons that prevented students from accessing help earlier were: busy freshmen year, a general feeling that things were going well, and a desire to identify as disability free student (Lightner et al., 2012).The inability of individuals with LDs to advocate for their own needs seems to be a pertinent barrier (Reed, et al., 2006). Hartman-Hall \& Haaga (2002) described the exposure to negative reactions from professors led to a reduction in reported willingness to seek help. Whereas, a positive response from the professors increased help seeking behaviour (Hartman-Hall \& Haaga, 2002).

Barnard-Brak, Lechetenberger and Lan (2010) identified three behavioural strategies in requesting accommodations in the postsecondary classroom which included: scripting the disclosure of their disability and request for accommodations; negotiating accommodations rather than reporting non-compliance with policies supporting accommodation; and downplaying their own disability status. Barnard et al. (2010) further identified that disclosure was influenced by self-acceptance and interpersonal skills held by students with LDs. Higgins, Raskind, Goldberg and Herman (2002) broke down the self-acceptance of LD in the following manner: labeling the event, understanding/negotiating the label, compartmentalization and finally transformation of negative attitudes towards LDs. Through research it can be verified that 
resilience is key to many of them which helps them surpass barriers through protective mechanism (Dole, 2000; Hall, Spruill \& Webster, 2002). Miller (2002) identified that major elements of resilience in students with LDs include: identifiable success experiences, particular areas of strength, self-determination, distinctive turning points, special friendships, encouraging teachers and acknowledgment of the learning disability.

Both internal and external factors build up resilience in individuals that may support as a coping strategy. Internally, personality characteristics, skills and values affect resilience (Dole, 2000). Also self-esteem and self-efficacy build into the internal factors to foster resilience (Watson \& Larson, 2006; Dole, 2000). Various studies support that self-advocacy and selfdetermination are important to form resilience for students with LDs that were transitioning from high school to post-secondary education (Field, Sarver and Shaw, 2003; Gil, 2007; Lock \& Layton, 2001; Roer-Strier, 2002; Price, Wolensky and Mulligan, 2002). Protective resiliency factors such as outlook on life, cognitive reframing and development of positive self-esteem also realized to be positive coping strategies (Shessel \& Reiff, 1999). Shessel \& Reiff (1999) present in their study that few participants identified the positive impacts of LDs on their lives due to protective resiliency factors. Through cognitive reframing, positive self-esteem developed which participants with LDs identified helped to make better persons, allowing them to think creatively, increasing their sensitivity to others, making them better professionals and developing within them a desire to help others (Shessel \& Reiff, 1999).

On the other hand, efficacy with family and support from school, work and community systems helps build resilience through extrinsic mechanisms (Dole, 2000; Cory, 2005). Individuals may employ positive coping strategies such as relying on benefactors such as parents and friends (Barga, 1996 and Wilcox; Winn \& Fyvue, 2005). Further coping strategies include: 
implementing self-improvement techniques (Barga 1996 \& Reed, Lewis and Lund-Lucas, 2006), utilizing time management skills, keeping daily/weekly schedule (Cowen, 1988) and keeping high levels of initiatives in everyday problem solving (Hall, Spruill \& Webster, 2002).

Moreover, removal of self from oppressive environments (McDonald et al., 2007; Hall, 2004), reframing dominant cultural narratives, discounting validity of dominant narrative, turning discouragement into motivation and replacing pejorative narratives with positive personal narrative were identified as positive coping strategies by McDonald et al. (2007). Individuals with LDs cope with exclusionary behaviours by traveling together and by supporting each other through story telling (Hall, 2004).

In contrast to the above mentioned strategies, negative coping strategies were also discussed in the literature review. "Passing" as a negative coping strategy is used to avoid disclosure about LD (Barga, 1996; Cory, 2005; McDonald et al., 2007). "Goodness of fit" is employed by participants as they purposely chose fields that were compatible with them (Madaus, 2008).

\section{Filling the Gap}

The present literature on LDs endorses the presence of both evidence-based and nonempirical based studies. Since LDs is a topic of discussion in the field of Psychology and Education, a copious amount of literature is focused from evidence based perspective. A significant number of studies were quantitative in nature including studies by Fredickson \& Furnham (2001), Gallegos et al. (2012), Hall et al., (2002), Hartman-Hall \& Haaga, (2002), Heiman \& Leinchentritt (2010), Kistner et al. (1987), Precel, (2003) and Zhao et al. (2008) dominate the scholarship about LDs as they focused into the aspects of emotional, personality relevant and academic abilities of individuals with LDs. Also, many studies incorporated an 
interpretivist paradigm which used a combination of qualitative and quantitative methods.

Studies by Reed et al. (2006), McDonald et al. (2007), Cowen (1988) and Higgins et al. (2002) used mixed methodology to conduct both qualitative and quantitative analysis on the findings. It was observed that in comparison to positivist and interpretivist research paradigms, qualitative or critical studies were limited about the impact of LD on individual's lived experiences. Studies that undertook this approach included those by McNulty (2003), Shessel \& Reiff (1999), Barga (1996), Hall (2004), Roer-Strier (2002), Cory (2005), Denhart (2008), Barnard- Brak (2010), Miller (2002) and Wilcox et al. (2005) which focused on aspects such as help seeking, supports while they looked into the areas of sociology, social psychology, child development and education psychology.

It was observed that a significant number of studies focused on the emotional aspects and coping strategies utilized by students to overcome the challenges of having a LD. However, limited research was encountered which revealed the experiences of students progressing from secondary school education into post-secondary institutions. Moreover, the presence of studies that utilize a social work perspective was found to be minimal through the literature review (Roer-Strier, 2002). Thus, there is a definite lack of literature that helps to understand the experiences of individuals with LDs through a social work perspective. Accordingly, to better understand the lived experiences of Canadian students with LDs, this research study focuses on adapting a qualitative approach through a social work perspective that allows us to observe the overall challenges that may be present for students to pursue higher education within Ontario. 


\section{CHAPTER 3. THEORETICAL FRAMEWORKS}

The major theoretical frameworks that are incorporated within the study include Critical Theory in Education, Goffman's work on understanding stigma, and Social Model of Disability.

\section{Critical Theory in Education (CTE)}

CTE is based fundamentally on Critical Social Theory (CST) which examines the social structures, institutions, policies, practices and processes with respect to how they treat all groups in the society (Mullaly, 2010). Critical theory began its development in the Frankfurt School, Germany during 1920s (Sever, 2012). It is founded on a Marxist philosophy that educational systems within capitalist societies are influenced by dominant social forces, which are incapable of fulfilling their democratic potential (Wotherspoon, 1998). The philosophical grounding of CTE lies within the ideology endorsed by Kant, Hegel and Weber (Sever, 2012).

CTE recognizes that social institutions such as the economic system, welfare system, education system and religious organizations are a major source of oppression (Mullaly, 2010). These organizations were formed by the most privileged groups of the society that have been dominating other social groups. These dominant groups include Christian heterosexual males of European origin, and thus reflect the views of this group generally (Mullaly, 2010). The dominant groups that run these systems hold privilege over other groups such as: people of color, the working class, non-Christians, women, etc. (Mullaly, 2010).

As framed by Kellner (as cited in Mullaly, 2010) critical theorists provide criticisms and alternatives to traditional or mainstream social theory which includes a critique of domination. The theory is driven by the goal of liberation from domination, inequality and oppression. The theory has a vision of society based on egalitarian values where social work practices are committed to move from the current unjust society (also referred to as mainstream or 
conventional society) towards a society that is free from dominant-subordinate relations (known as progressive, transformative or critical society) (Mullaly, 2010).

The sociology of education's focus on the relationship among social structures, power and schooling practices came through with the advocacy from a group of educational researchers in England during 1970s (Sever, 2012). The instrumental view of education describes the education system as an input and output system where curriculum and teaching are perceived as a means to control specific purposes that have not been discussed (Hargeaves et al., 2003). Here, difficulties within the educational system are ascribed to teachers' or students' inadequate behaviours or to the inefficient use of resources (Hargeaves et al., 2003). CTE counteracts this view while supporting that schools contribute to social, ideological and labour force reproduction (Wotherspoon, 1998). Gibson (1986) recognizes that the performance of white middle or upper class students has been discussed in comparison to the performance of students that belong to working class or to certain minority groups due to the latter's relatively low performance in education.

Theories of cultural reproduction, resistance theory and critical pedagogy collectively form the critical theory of education through grounding in sociology (Sever, 2012; Wotherspoon, 1998). CTE holds that the education system has been unable to promote a more egalitarian society as it is focused on the growth of dominant social groups (Wotherspoon, 1998). CTE targets the reproduction of capitalist social order based on class system which occur through the contributions of the "hidden curriculum" (Morrow \& Torres, 1994). Reproduction theorists advocate for equality within the education system while opposing the mainstream ideology which it recognizes works to maintain power relations while being agencies of dominant class or culture (Demaine, 2003). 
Resistance theory serves to counteract the reproduction process through human agency, equalizing learning opportunities within the school system for students (Giroux, 1983; Wotherspoon, 1998). The concept of resistance within the CTE explains the existing tensions between students and schooling processes. Studies within this sphere focus on oppositional or rebellious student behaviours that overcome a passive political stance against the education system that sets them up for academic failure (Apple, 1982; Giroux, 1983). Wotherspoon (1998) explains that students may experience the transmission of education of curricula differently based on factors such as their gender, race, ethnicity, and age.

Critical Pedagogy has been recognized to be a mode that helps connect CTE in a practical manner as it fills the gap between understanding educational reproduction and taking action to provide social and educational transformation (Giroux and McLaren, 1989; in Wotherspoon, 1998). Through the lens of critical pedagogy, Freire puts forward that individuals who belong to the underclass or are oppressed don't have an equal share or the benefits of education (Kellner, 2003). However, these individuals should not expect education to be a gift from the privileged in the society (Kellner, 2003). Freire endorses the need to develop a 'pedagogy of the oppressed' where the oppressed educate themselves through a form of decolonization and a consciousnessraising. Through a critical pedagogy of education it is essential for the students to engage in dialogue with teachers and to fully participate in their educational process (Kellner, 2003). Further, the students who may be oppressed would be able to create better lives for themselves through social transformation and empowerment while refusing to conform to the dominant views and values (Kellner, 2003).

Emancipatory interest and reflexive learning are major components of Critical Theory (Hargeaves et al., 2003). Emancipation is dependent on the capacity for an individual to act 
rationally and to be self-determined and self-reflexive. Hargeaves et al., (2003) state that selfreflection assists in overcoming the limitations caused by the internalization of social rules. And that self-reflexivity as described by Habermas (1975) is related to societal empowerment and rehabilitation of the public sphere. John Dewey linked education and democracy where he stressed the critical importance of education on maintaining a democratic society (Kellner, 2003). Further, he stated that education should be accessible to all in order for democracy to function, which would in turn provide a good life and good society (Kellner, 2003). CTE therefore promotes the need to restructure education to radically democratize education while applying Deweyean and Freirean conceptions to develop individuality within students and to promote citizenship and community by strengthening democratic participation (Kellner, 2003). Further Kellner (2003) advocates that students may be pushed to follow the curricula and agendas set-up by the teachers and educational authorities; thus displaying the Hegelian 'master/slave' dialectic which could characterize current relations between students and teachers.

\section{Stigma}

Goffman (1963) explains stigma as a concept that is used to refer to an attribute that is deeply discrediting almost anywhere in our society. Goffman (1963) breaks down stigma into three different types which include (i) physical body deformities, (ii) perception about individual's character or personality (i.e. weak will, domineering or unnatural passions) and (iii) tribal stigma of race, nation and religion. In our society stigmatized person is looked upon differently in ways that imply that he or she is less human (Goffman, 1963). A glance from members of the society that may belong to the "normal" reduces the whole person into a tainted and discounted individual (Goffman, 1963). In the more recent literature about stigma, public 
stigma is understood to operate when the society validates the stereotypes about a disease or disability and then discriminates against individuals that display those (Jones \& Corrigan, 2014). Individuals who belong to the stigmatized group may find themselves being constantly worried about being judged; where it becomes common for stigmatized individuals to question what others "really" identify and think about them (p.14; Goffman, 1963). Further, Goffman (1963) identifies that our society begins to apply categorizations in social situations that incorporates an individual known or perceived to have a stigma. These categories may not fit, during which both the members present within the situation and the person that belongs to a stigmatized group likely experience uneasiness (Goffman, 1963). Further, the individual may feel unsure and stressed about how he or she may be categorized by others. Jones and Corrigan (2014) help understand Self-Stigma which occurs when an individual begins to internalize public stereotypes. These individuals apply self-stigmatization that is described by the "three A's: awareness public stereotypes, agreement with these stereotypes, and application of one or more stereotypes to self" (p.18; Jones \& Corrigan, 2014). Self-Stigma leads to the application of negative self-concept whereby diminishing self-esteem and hope within the individual (Jones \& Corrigan, 2014).

The stigmatized person may attempt to do "normification" where he or she applies effort to present themselves as an ordinary person, while not necessarily concealing their failures. Also they could attempt to use "passing" as a strategy to conceal their differences or failures to falsely identify themselves as a part of the normal group (Goffman, 1963). This is done when their differences aren't apparent and they choose to not disclose discrediting information about themselves. Stigmatized individuals who are ready to admit the possession of the stigma may use "covering" as a way to apply efforts to keep their stigma from increasing (Goffman, 1963). The 
goal maintained by the stigmatized individual is to reduce tension through their stigma, and focus on the official content of the interaction (Goffman, 1963).

Recent literature further elaborates Goffman's idea of concealing stigmatizing characteristic through label avoidance. Label avoidance is understood to be a mechanism where individuals decline services with an attempt to avoid being labeled or stereotyped (Jones \& Corrigan, 2014). As Jones and Corrigan (2014) explain, it may easily present within students with LDs that do not wish to be stereotyped as less capable or less hardworking students. Label avoidance is thus connected to public stigma and self-stigma. The fear of being characterized by the society as a stigmatized person and the personal fear of gaining these characteristics prevents disclosure through label avoidance (Jones \& Corrigan, 2014). Finally, Jones and Corrigan (2014) identify that structural stigma is based on private or institutional rules, regulations and norms which discriminate against individuals with stigmatized conditions intentionally or unintentionally. Unintentionally, these rules or norms may exclude the participation of stigmatized individuals while setting up structural barriers (Jones \& Corrigan, 2014).

\section{Social Model of Disability}

The dominant perspective of disability is rooted in the Medical Model which focuses on the individual body (Oliver, 1990). Disability is pathologized as a physical or mental impairment of a person (Oliver, 1990; Prince, 2009). It focuses on the difficulty and restrictions experienced by the individual due to their condition, which reduces their involvement in daily activities (Prince, 2009). Thus, the Medical Model vastly ignores the connection between social environment and disability, while it focuses on individual impairment (Oliver, 1990). Oliver explains that the medical model of disability is limited in its scope as it fails to include social aspects within itself through wider aspects of disability. It aims to cure, prevent or adapt the 
person's impairment(s) as it reinforces the notion about disability being present within the individual. Consequently, it has brought forward interventions that care for and help those in need through the rise of charities (Oliver, 1990). Further, Prince (2009) highlights that Canadian federal and provincial laws also define disability in relation to impairments.

In contrast to the mainstream understanding of disability, an alternate perspective is the Social Model of Disability. This perspective is based on social rights or socio-political stance (Prince, 2009) that arose in response to the dominant medical model of disability (Oliver, 1990). It understands disability as social reactions or barriers to impairment which decrease individual's participation due to discrimination, social exclusion and marginalization (Oliver, 1990). Disability theory focuses its attention on attitudes, beliefs, body identities, and social values, issues of human rights, prejudice, and stigma in relation to disability (Prince, 2009). Disability is thus understood as social exclusion that results from socio-economic, cultural and political disadvantages inflicted on a person (Prince, 2009). Hence, the focus on disability theory is not on the individual as perceived by the mainstream notion, but is on the social processes.

By applying Oliver's definition of disability, it can be comprehended that a learning disability is a social reaction or barrier to a learning difference. This learning difference is considered to be impairment from the norm of typical learning style or mode (Prince, 2009). Thus, individuals with LDs experience discrimination, social exclusion and marginalization due to their non-conformation to the mainstream society's idea about typical learning. Oliver (1990) states that by treating a difference in modalities as a social restriction, rather than an individual flaw will contribute towards creating a society that is more inclusive and oriented towards social justice. Through disability theory it can be conceptualized that individuals with disabilities face fundamental obstacles to full participation as they are not recognized as full persons in the 
prevailing cultural value patterns (Prince, 2009). Further, resources are mal-distributed in the form of income, employment, housing and other material resources (Prince, 2009).

The social model of disability differentiates between "impairment" and "disability". Here, "impairment" refers to specific physical or functional constraint that an individual may encounter which is personal and private (Shakespeare, 2013). Consecutively, "disability" is considered to be public and structural, where it a social creation that disadvantages individuals due to societal responses to their impairment (Shakespeare, 2013). The Social Model suggests that the disadvantages encountered by a person with a disability are not due to their individualized impairment but due to exclusion and oppression which are socially constructed (Oliver, 1990). Through this view, the "impairment" may not necessarily hinder the progress of the person; however the social construction of "disability" deters their progress. In opposition to this model, Critical Disability theorists such as Tom Shakespeare (2013) offer an alternate perspective while highlighting the limitation of the Social Model. Shakespeare (2013) identifies that the Social Model ignores or minimizes the intrinsic impact of the impairment on the individual that could significantly lead to their disadvantage. Since the framework for the current research study is structural, the Social Model of Disability is appropriate to understand the nature of the disadvantages faced by individuals. Thus, rather than medicalizing or pathologizing "disability" as an intrinsic impairment, in this study it is perceived as a social construct. Further, the Social Model connects this disadvantage to the capitalist system as well (Shakespeare, 2013).

\section{Summary}

The study utilizes Critical Theory of Education, Stigma and Social Model of Disability as frameworks to serve the function of social justice. These frameworks would collectively help understand the experiences of a student with a LD within the education system. 


\section{CHAPTER 4. METHODOLOGY}

\section{Phenomenological Method of Research}

The study utilized phenomenology as its methodology to collect data in a setting that was sensitive to the participants in the study (Creswell, 2007). This study aims to explore the meaning individuals or groups ascribe on a social or human problem (Creswell, 2007).

van Manen (1984) describes phenomenology to be a study of lived experiences. It is based on philosophies by Kant, Hegel and Husserl (Groenwald, 2004). This methodology helps to deepen our understanding about the experiences (Wilcke, 2002). Groenwald (2004) states the aim of phenomenology is to describe the phenomenon most accurately while refraining from any pre-held notions or biases. By using bracketing and self-reflexivity as identified by Husserl and Heidegger (as cited in Groenwald, 2004) respectively, I attempted to keep aside my own notions about the phenomena of being a student with LDs (Byrne, 2004). Although, this process was very difficult to achieve, I tried to limit the number of questions I would ask during the interview with participants, and asked for the participant's clarification to obtain their personal reflections of the phenomena. Through this, I aimed as a researcher to be true to facts as portrayed by the participants (Groenwald, 2004). Phenomenology does not seek to conceptualize, categorize or theorize about the experience; rather it aims to gain insightful and a deeper understanding of everyday lived experiences of individuals (van Manen, 1984). Within this methodology, the lived experiences, or the realities experienced by the participants are treated to be absolute data or 'pure phenomena' (Groenwald, 2004).

Further, rather than focusing on the experience of a single individual, phenomenology describes the meaning of several individuals' lived experience of a concept or a phenomenon by exploring what is common between the experiences of the individuals (Creswell, 2007). 
Heidegger (1962; in Wilcke, 2002) elaborates that although it is possible to have generalizations about the human conditions, we should also value that every individual demonstrates their own unique experiences. The current study seeks to explore the lived experience and its essence for students with learning disabilities who have been able to successfully pursue post-secondary education. While recognizing the similarities and differences between their experiences, the study will help understand the essence of the experiences.

With an inductive data analysis process the researcher works in collaboration with the themes and database to establish a comprehensive set of themes while exploring the patterns and categories through a bottom-up process (Creswell, 2007). The final product of the study presents the voices of the participants and the meaning they ascribe to the issue being studied (Creswell, 2007). Further, the complex description of the problem is formed through the reflexivity of the researcher which informs the interpretative inquiry that is formed by what the researcher sees, hears, and understands about the problem (Creswell, 2007). It further extends the literature or may signal to call for an action (Creswell, 2007).

\section{Criteria for Participation}

Students who are currently enrolled in a college or university and identify to have a learning disability prior to their postsecondary education were recruited for the study. This criterion was set in order to explore the experiences of students in secondary school system; as it would further help understand the experiences that led them to post-secondary education. Any interested participants over the age of 31 years were not considered for the study.

\section{Procedure}

A voice recorder was used to record the interview with prior consent of the participant to help conduct data analysis for the study. The interviews were of 60-90 minutes duration, and 
were held at settings that were suitable and comfortable for the participants. Semi-structured open ended questions were used during the interview with the intention to explore and uncover of participant's own interpretations of their experiences (Wilcke, 2002). The semi-structured nature of the interview provided participants with the control to guide their interview based on their experiences. The sequencing of the questions was determined to be dependent on each participant's individual responses (Chilisa, 2012). Thus, the participants had the authority to discuss their experiences in a manner that suited them. The purpose of having an interview guide for the interview was to ensure that the research question can be discussed through the interview with all the participants (Chilisa, 2012).

During the interviewing process, as well as in the analysis, I consciously attempted to bracket my own presumptions about experience of the participants (van Manen, 1984). Lester (1999) describes that it may be difficult to be completely unbiased from the influence of our professional experiences and research knowledge. Thus, in extension to bracketing; in the research paper I will explicate my assumptions and pre-understandings about the topic (van Manen, 1984) which I have attained through my involvement as a service provider for individuals with LDs. Upon the completion of interviews with the participants, transcription of recorded interviews was conducted. The experiential descriptions from participant's narratives and locating it within the present literature was then performed (van Manen, 1984).

\section{Sample Recruitment}

The participants for the study were recruited through on-campus postings of study flyers and through email listserv of Ryerson University. Also, members of Learning Disabilities Association of Peel Region (LDAPR) were contacted for the study through posters and email listserv. Further, snowball sampling method was employed where potential participants could 
forward the researcher's contact information to other potential participants, who may contact the researcher to participate in the study.

\section{Data Analysis}

Data analysis of the study reflects the essential themes that characterize the phenomena (van Manen, 1984). The interview transcriptions facilitated with the data analysis process to elucidate the essence of the participant's lived experiences. By thematizing the narratives of the participants, the study aimed to explore the "essence" or the meaning that participants ascribed to their lived experiences (van Manen, 1984). The method applied in this study was adapted from Cresswell (2007). Firstly, the personal experiences of the participants are described in relation to the phenomena studied. The researcher writes his/her own experiences in a specific section as an attempt is made to focus on the experiences of the participants (Cresswell, 2007). Although, it is not possible to completely bracket the researcher's own experience and views, best effort is made to draw a line between the description of the participant's experiences and the researcher's views. Next, it is important for the researcher to develop a list of significant statements to understand how the phenomenon has been experienced by the participants (Cresswell, 2007). These statements are then listed by the researcher and are given equal worth, while the researcher works to produce a list of statements that are non-repetitive and non-overlapping (Cresswell, 2007). Subsequently, the researcher takes the list of these significant statements and groups them into larger units of information or themes (Cresswell, 2007).

Once the themes have been established, the researcher writes a textural description of what was experienced by the participants in the study with the phenomenon. During this process, the researcher includes verbatim examples from the interview transcriptions (Cresswell, 2007). The next step involves writing a structural description of the experience. Here the researcher 
emphasises on the setting and the context in which the phenomenon took place. The final step in the analysis includes writing a composite description of the phenomenon that incorporated both the textural and structural descriptions which entails the "essence" (Cresswell, 2007).

\section{Self-Reflexivity}

herising (2005) identifies social location is critical to deconstruct the power held by researcher. While pursuing this study,. I recognize being a 23 year old female researcher who is currently enrolled in the Masters of Social Work program in a Canadian University. I was previously a service provider for individuals with LDs. Being a researcher, I aimed to be an ally rather than an "authority" figure. I attempted to credits the subjective knowledge held by the participants. Rather than confining the study, the interview space was kept open to modifying the questions to further encourage the participants to share their stories or views that are significant to them through my ongoing dialogue and collaboration with the participants (Fitzgerald, 2004; George, 2013). However, I must acknowledge that as a "researcher", I experienced that I held power and privilege while I conducted the study and analyzed the data to derive the essence of the experiences. (Soyini Madison, 2004).

\section{Ethical Considerations}

The study participants had self-selected for the research study based on their interests. Noting the emotional value of the lived experiences, the participants had the opportunity to determine which of their personal experiences they wanted to share for the study purposes. The participants were informed prior to the interview that they could ask to stop or pause the interview at any time to suit their comfort. Further, they were provided the option to withdraw from the study at any time with no repercussions. To develop a rapport with the participants and to confirm the participant eligibility, the researcher had communicated with the participant over 
the phone prior to the interview. The data obtained for the study was kept confidential. Further, to represent study findings, participants were asked for their preference for a pseudonym to replace their real names. In an absence of any preference, a random name was selected for them.

\section{Limitations of the Research Design}

The research study is based on the experiences of 4 participants. Due to a small sample size, the findings cannot be generalized beyond these participants. Phenomenology focuses on the lived experiences of individual in their unique setting. This makes it difficult to further generalize the challenges or strategies that can be used by a general population (Wilcke, 2002).

Due to the length of the study period, it was not possible for me to bring back my interpretations to the participants. However, if the study were to be extended, it would be a priority to check with the participants about the interpretations. While keeping these limitations in mind, the study presented findings that deepen our understanding of certain aspects of the experience held by students with LDs. 


\section{CHAPTER 5. FINDINGS}

\section{Introducing the Participants}

The study sample consisted of four participants who were recruited from Southern Ontario. The sample represents a diverse group that completed their primary and secondary school education in public, private and faith-based school systems. Further, the participants identified themselves as members of distinct ethnic communities which included Portuguese, South Asian, Jewish and Irish. Some racial diversity and socioeconomic class differences were observed within the group. It is interesting to note that all four participants were women and were currently university students enrolled within helping professions. The names of the study participants have been replaced with pseudonyms to maintain the participants' confidentiality. Andrea: Andrea is a 26 year old woman who is currently a graduate student. Andrea attended public school throughout her primary and secondary school education. She identifies her LD in processing and differentiating.

Becky: Becky is a 22 year old woman completing her undergraduate studies, prior to which she has also completed a college diploma. Becky's primary and secondary school education was completed in public school settings. Her LD is in the areas of comprehension and written expression.

Claudia: Claudia is a 24 year old woman who is currently a graduate student. Throughout her primary and secondary school education, Claudia studied in private schools. Claudia states Attention Deficit Disorder (ADD) to be her LD.

Hannah: Hannah is a 31 year old woman who is currently pursuing undergraduate studies. She has also achieved three college diplomas in Business Marketing, Paralegal and Legal Assistant. Hannah identifies Dyslexia as her LD. 


\section{You have a learning disability...}

Three of the four participants, Andrea, Becky and Hannah, were formally diagnosed with their specific learning disabilities when they were in elementary school.

Andrea and Becky described being taken away from their regularly scheduled classrooms by teachers and were required to take several tests constituting Psycho-educational assessment.

I remember the interaction and feeling kind of odd. Like what are you? No one really explained it to me about what was going on. They were just asking me a bunch of questions apart from my classmates. But at that time ... I didn't really know what it meant. (Andrea).

From the above, it can be perceived that Andrea felt confused at the time of her "diagnosis" due to lack of awareness about the testing procedures. Also, Becky explained, “... I felt very intimidated and felt very awkward for being with someone one-on-one and not knowing why you are there ... and you are expected to do so many things. I didn't feel comfortable.” In the public school setting, both the study participants felt "awkward" or "odd" for being taken away from their grade 3 classrooms for psycho-educational testing. Subsequently, Hannah described that she found the testing method "not negative, not positive. It was what it was." She further stated not recollecting any strong feelings about the testing. The fourth study participant, who was enrolled in a private school, described being diagnosed with her LD in grade 8.

They [teachers] made comments to my mom about my acting out and stuff, not raising my hand and being I guess jumpy. But I don't know. So they told my mom to get assessed. My mom's a social worker. She knows how to talk to me. And we have always been open with each other. So she was like, 'this will be best to help you to learn' and I understood that you know. And then I went to see some woman I remember. And I don't remember a lot about the assessment but I remember she told me about what kind of learner I was, and diagnosed me with ADD ... I didn't really internalize it. I kind of I just thought it was something I had to do. (Claudia)

Through Claudia's experience, it seems that the process of being diagnosed was not as stressful to her since she was provided with encouragement and insight from her mother. Claudia 
felt indifferent and comfortable through the process, as she trusted her mother's suggestion. Although, Claudia described not "internalizing" what the process meant, she perceived it as a standard process. Further, Claudia was tested outside of school setting, thus her experience of being tested did not comprise of being taken away from a classroom with her peers.

Thus, it can be seen that the experience of being tested with a LD was similar for Andrea and Becky who were pulled out from their regular classrooms to be tested. They both felt uncomfortable and confused about the testing as it was conducted during the school time. Further, both of them did not understand what was happening at the time of testing, and how it would impact them. However, Hannah described her experience as neutral where she neither felt good or bad about it. Claudia, on the other hand, had the opportunity to go through the testing outside of school with her mother. This allowed Claudia to feel comfortable about the testing as she was provided an explanation for what was happening.

\section{In the Primary School Classrooms...}

This section will discuss the experiences of the participants within their classrooms during their elementary and middle school education. Andrea, Becky and Hannah went to a public school for their elementary and middle school education. Andrea described that she was placed in a segregated classroom to accommodate for her LD.

It really-really hit me, that I knew there was something different about me. Maybe something wrong, because I was put in a much smaller class right, like even when they would try to pull me out of the class I would be like, 'No I don't even want your help' I was very like 'No, I don't want this, go away'. (Andrea)

Andrea actively seemed to resist her "accommodation" while refraining to acknowledge her LD or need for assistance. Further the notion of feeling that there is "something wrong" or "different” about herself, Andrea struggled emotionally as a student with LD. Andrea explains her resistance of two years against being placed in a segregated classroom: 
I knew there was something wrong about it. I didn't agree with it. I begged my teacher literally begged my teacher... 'please I don't want to be here' and he transferred me into you know regular classes and I felt much better. But I still, there was that shame there right. (Andrea)

Similar to Andrea's experience, Becky was also placed into a segregated special education classroom which had a negative impact on her experience as a student.

... in elementary school I felt very isolated than when I was in high school or postsecondary. They often take you away from the rest of your peers and stuff ... It would limit my chances of getting to know my peers and building a relationship with them. I think I was bullied throughout elementary and middle schools. It was one of the main reasons because of me being isolated from everybody else ... I had a really hard time to be honest with you. I had very little or no support with my peer support. I had no friends. (Becky)

Through this narrative that Becky presents, it appears that the ways of accommodating her LD at school led to her unhealthy school experience. Becky experienced bullying and isolation while she was placed in a special education class for receiving accommodations. Further, she described that her experience with teachers coming to pick her up from her regular classroom felt as a "label", which was "a constant everyday thing". On being pulled out of her regular class Becky explained, “... like ok everyone knows where I am going. Everyone knows I have a learning disability now, right. So it just felt really uncomfortable". The lack of confidentiality about her LD within her regular classroom further strained Becky's relationship with her peers. She also expressed her disapproval of the special education classroom:

It didn't make sense...my class and when I was in my Special Ed. room we learnt the same thing but it would be a little bit different. Like it did help but I didn't like the fact that why am I learning the same thing as my other peers but I am separated from them. It made no sense. (Becky)

Through Becky and Andrea's experience of being placed in a segregated classroom, it can be assumed that the two participants detested any help or accommodations during their elementary or middle school education. Further, feelings of embarrassment, discomfort and 
disapproval appear to be common in the above mentioned classroom experiences of Andrea and Becky. Moreover, Becky described feeling that elementary and middle school teachers were not “as patient with kids with learning disabilities". She stated feeing unconvinced about the training held by the teachers as she felt "they were not too aware as to how to teach a student with learning disability ... [and] they underestimate students who have learning disabilities." Moreover she noted:

Sometimes like my Special Ed. teacher in middle school would come and sit right beside me as if I needed his assistance all the time ... I feel like in middle school, elementary school they make you feel like you are so dependent on your Special Ed. teacher ... I felt like more controlled ... And in grade 8 my teacher told me that I am not capable enough to go and take applied level courses. (Becky)

Through the interviews, it was noted that Becky and Andrea experienced deprivation of opportunities that were present for their peers in the mainstream school system. Becky stated "I didn't learn French in middle school. When the rest of my classmates were studying French, I was taken away and sitting out. Because they thought that I was not capable of learning French”. Moreover, both Becky and Andrea stated being directed by their teachers to enrol into vocational programs for Grade 9 at an alternative high school. Andrea stated "they wanted me to go to an alternative school so this school was, with people with learning disabilities, people with behavioural issues." Surprisingly, Becky who was also attending public school stated having a very similar experience of being placed in an alternative school for grade 9. She described, "It felt really weird. Because I knew I had more potential, I can do more than that ... I was hurt. Like I felt like I was put down". Further account of Andrea and Becky's grade 9 experiences at the vocational or alternative school will be discussed in the section containing high school experience. 
Becky also had another challenge that she described in her elementary and middle school experience. Being a racialized student whose first language was not English impacted her diagnoses of LD. She stated, "They thought that my English was my main issue. It was more than that. I had reading comprehension and written expression..." Becky explained feeling "misdiagnosed" which consistently impacted her learning in the elementary and middle school classroom as she was not appropriately accommodated.

Hannah described her classroom experience as "frustrating" as she explained that although she had good grades without accommodations, she was unable to get "right things down". While she tried to talk with teachers about this, she stated being unsure if the teachers "didn't agree with [her LD], or believe in". She further stated:

I got to a point where I was like frustrated with having to go to the teacher, and like talk to the teacher about it and having like some teachers be responsive; like positively responsive to it, and having some teachers just not care. (Hannah)

In contrast to the other participants Claudia received her elementary and middle school education in private schools. She described, "I always had small class sizes, which I enjoyed. And then I could get individual attention ... I feel like probably grade 7 and 8 I got extra school help". Further, she explained "I didn't think anything of it [LD] when I was younger. I think only when I got to university, when I realized that that's what is inhibiting me from doing the things that are more typical." She further described, "I had a good relationship with my teachers. But I was still a troublemaker; like I did get sent to the principal's office or I would come to school late." She described her friend's circle where she "was always like a ring leader" and she had a good group of friends in her elementary and middle school days.

Through the above section, it can be derived that each of the participants had their individual experiences of being a student with a LD in primary school. However, prominent 
similarities of feeling at unease can be derived from Andrea, Becky and Hannah's experience of studying in a public school classroom. Further, their experience seems to be considerably different from that of Hannah's who studied in a private school; and described a positive experience in the classroom.

\section{At the High School...}

The four participants studied in diverse education systems through high school. Andrea and Becky continued to study in public schools. Hannah switched to a faith-based school for her secondary school education. Meanwhile, Claudia continued her studies in a private school. This section will discuss the participants' high school experiences.

Due to Becky's challenge of gaining the appropriate accommodations during her primary education, she stated that in high school she was finally "diagnosed properly". She described her high school experience as:

... usually in high school there would be a specific course you would take. And that's where special education teacher would help you, where you get your accommodations met. And the people wouldn't know that you have learning disability ... It's like your own course that you are doing in a separate class ... it felt nice. (Becky)

It's interesting to note that Becky expressed feeling more comfortable with her LD once she was accommodated after being "properly diagnosed". She stated, "they gave me a reason about what I had, and what were some of the things that could help me”. As Becky explains, "For example, if I had a test before my classes, I would do it with my Special Ed. teacher. I would get extra time and get a proper accommodation of getting extra time." Becky felt "nice" as she continued to work with her classmates without feeling isolated in high school. She described, "So I got a better understanding, and I was at the same level as the other students. So, the learning space really makes a big difference.” Although, both Becky and Andrea attended public 
schools for their secondary education, they both expressed contradicting feelings of being students with a LD in a secondary school classroom. Andrea described her experience as;

Kinda demoralizing. Like I didn't really, like at high school level, I think they need to be a little bit more sensitive. You go into a separate classroom, or it was more known that you have a disability. There needs to be more of that confidentiality and challenging that stigma. (Andrea)

Although, both Becky and Andrea had a similar experience of going to another classroom to get help in their high schools, Andrea described her experience to be negative in comparison to Becky's experience.

Andrea also described that she took comfort in "being lost" amidst school transfers from vocational to mainstream programs. Since, her documentation for $\mathrm{LD}$ were not passed onto her new school, Andrea went through most of her high school without any accommodations. Although, she did not perform academically well, she felt comfortable about not being labeled for her LD. However, she stated that in grade 11 when she began to take her academics really seriously, she decided to pursue university education.

I went to the counsellor and then they were like, "yeah you need the support"... So I suppressed it for so long. I never had it, I never even thought about it for years. It didn't really impact my life at all. And then towards the end, when I wanted to go to postsecondary and then yeah (Andrea)

Andrea described denying her LD as she refused to seek help. Reflecting back to that time period she stated feeling, “... stupid, or no I wasn't capable”. Further, she noted, “And at that time, I really-really wanted to go to postsecondary. For me having a learning disability made it, not being able to go to postsecondary." Thus, initially, Andrea objected to being "labeled" as a student with LD, as she associated the label to her not being capable to pursue university. However, while trying to dissociate herself with LD, she also lost her accommodations which 
impacted her grades negatively. Thus, she finally approached her counsellor to disclose that she needed support to make it to university.

Hannah who studied in a faith-based school described that her school was really strict. She stated having immense pressure and competition to get good grades. Further, she noted that the classroom sizes at her school were very small, since her school was previously a private school which was made public. Hannah identified that she was pushed to pursue this high school against her will, "I didn't really have a choice about what high school I went to. Like my mom said, 'You are going to this high school', I didn't have a choice." Hannah explains having a difficult time to get accommodations for her LD during high school.

Like I asked, and I told them [high school teachers] about all the stuff from elementary school and they just would say 'we will get to it when we get to it kind of attitude.' And then because I was really shy and really embarrassed about it. I didn't really keep approaching them about it. And my mom was like, they will take care. She kind of had the same thing. 'Don't worry they will do it. They said they would they do, they are going to do it.' But they didn't really do. So a lot of frustration. (Hannah)

By not being accommodated for her LD, Hannah described feeling frustrated and hopeless as she began to stop approaching her teachers for help. Hannah also described that if she was at another school, she may have been more willing to talk about her LD with her teachers. She stated that being a "religious school', the teachers were very strict, and attributed that if you are unable to complete school work you were not only "stupid" but were also "a bad person". Hannah noted that this situation was emotionally challenging for her as she felt constantly pressurized. The fear of being labeled as "stupid" and "bad person" by her high school teachers prevented Hannah from approaching them for help. She described that her experience of being at that school as stressful. She also described;

I used to drink a lot in high school just because I was trying to deal with everything ... like high school that was very high pressured made everything worse ... then, I was 
really stuck and I tried to be positive but it was really just I couldn't be because I felt the whole world was against me. (Hannah)

Hannah struggled to gain accommodations from teachers to perform well at her high school, which reflected on her having a "really low self-worth, self-confidence". Hannah's high school experience differs from that of Becky and Andrea's experience as she did not experience being placed into a segregated school or vocational program. However, being a part of the mainstream schooling she experienced challenges in her faith-based high school. While Becky and Andrea had access to accommodations; Hannah struggled to get help from her teachers, and felt distressed about being placed in a highly competitive school.

Meanwhile, Claudia completed her secondary school education in a private school. She described her school to be "casual private" as the students didn't have to wear a uniform, and the school had a "welcoming open environment". She described a comfortable schooling experience through her high school as the students were "on a first name basis [with the teachers], like open door policy type thing”. Further, she stated, “... I think because of the small environment that I had in elementary and high school, that kind of helped me. Yeah. Because everything was tailored to my needs." She also described her experience about disclosure of her LD as such;

I am very open with it. And I am comfortable. I have never had people say anything to me or anything. If it did happen then I think I would stand up for myself because, or if people talk about some disability that I don't have, in some negative way I still talk about that. Cuz, but I never had any bad experiences really that I can remember. But I think that's because I am so open and comfortable with it. (Claudia)

In contrast to Andrea, Becky and Hannah who felt the need to conceal their LD during their K-12 education from their teachers or peers; Claudia described feeling comfortable and open about her LD as she recollected having positive experiences in her primary and secondary school education. 


\section{Programs, Streams and Alternate Schools...}

Becky described that the vocational program at the alternative school was "really stupid" as they "put kids who have learning disabilities into specific programs into high schools, below applied level. So, it makes you feel like you are stupid". She described that teachers in the program do not believe in the potential of the student. Further, Becky described "I got out of it after grade 9. Because I knew I had more potential than that ... but I stayed in that school because apparently there is a lot of support at the school." Becky further described the nature of the program, and its impact on her through the one year she stayed at that school.

To be honest, I felt like I had very little self-esteem when people treated you like that. Like, it' just like 'what, just because of learning disability you think I don't have potential to do this' ... the vocational program was way too easy for me. Like ok I just got to get out of here. Literally you learn like division and multiplication. That's like basic math and stuff ... (Becky)

Andrea described her short experience with the vocational program at the segregated school where she went for two weeks and "hated it". She stated, "I felt that there was something wrong with me ... and for some reason I was like, 'this is not where I want to be' ... and I got transferred because I asked for it." It can be noted that both Andrea and Becky felt uneasy at the vocational school. Their experience resonates with difficulties in relation to being segregated and labeled as being "different" or "stupid" as the participants described. Further, they both resisted the segregation as they asked to be moved back into mainstream classes. However, being in a faith-based high school, Hannah had a different experience in regards to selecting courses and streaming:

We had basic, advanced and enrichment classes. I was in advanced class, and I did some enrichment classes. But the friends that I had were mostly from the enrichment classes. And if you were in all enrichment classes then you were stupid. And which I kinda felt. (Hannah) 
Hannah also noted that she always aimed to attain at least $70 \%$ in her classes, so she wouldn't be bumped down to basic level classes. The basic level classes, as Hannah described took away the opportunity from students to apply to university or college. Thus, Hannah had the consistent pressure to score well in order to retain her eligibility to study at a college or a university. However, in contrast to the stress expressed by Andrea, Becky and Hannah; Claudia's experience with streaming was much simpler, as she described, "I think the only ones that were applied umm. I don't even remember it not being an option [for me]. But it being a question for me. I always knew I was going to university”.

Through this section it can be noted that there was significant stress among Andrea, Becky and Hannah in regards to streaming. However, Claudia received support and resources from her teachers in a private school setting which helped her to feel confident about pursuing university. Consecutively, Claudia did not have to worry about being placed in the mainstream school system or in applied or vocational programs.

\section{My Career Aspirations...}

Andrea described that she never wanted to go to college but always wanted to go to university. Further, she explained in regards to her current education, “... hopefully I will get to work with students with learning disabilities right. Because I don't want anyone to feel the way I did. I don't think it's fair." Similar to Andrea, Becky's inspiration for her career also originated from her personal experience as she described her aspiration to help marginalized individuals within the community due to her own experience as a student with a LD. She stated, "I knew how it felt to be marginalized and how it feels to be different and be treated differently in the society ... I want to assist ... [those] who are differently abled [or] marginalized". Moreover, 
Hannah also described her career plan aligned with her personal experience of being a student with a LD.

I think if I would have had someone who had advocated for me, on my behalf I could have gotten so much more ... support than I did. And I think it's really important that kids who do have learning disabilities or come from different situations have someone that can stand up for them ... my childhood was really messed up and I had to overcome a lot. I just want to help other children and youth who have been through that and just be there for them to advocate and support them. (Hannah)

However, Claudia described that she was inspired to pursue a career in the helping

profession by her mother, and through her experiences of volunteering at camps.

Well, my mom was a social worker. So I kind of, when she would come home and tell me about her cases when I was younger, I was just so intrigued and I didn't realize that there was all this stuff going on in this world because I was in this bubble you know... I was so infatuated and I started volunteering with her and. That's when I was like I want to work with people. And then I loved talking to my friends about their issues... (Claudia)

It can viewed that Andrea, Becky and Hannah were inspired to pursue helping

professions to advocate and support marginalized individuals; as they did not want others to go through what they did in regards to their difficult experiences as students with LDs. Although Claudia was also pursuing education in a helping profession, her motivation differed from the other three participants, as it was not based on personal experience with marginalization.

\section{Relationships in High School...}

Andrea states that her experience with certain teachers in high school was very negative as they discouraged her from pursuing higher education and set limits to her progress.

And I actually have really-really negative experiences with certain teachers. Like I had certain teachers tell me, 'you know what you are probably not made out for postsecondary', 'you would probably do better being a hairstylist or being in trade'. So that stuff really impacted me right (Andrea)

In a similar manner, Becky described that many teachers in the vocational high school would set limits to the achievements of the students. She stated feeling as though these teachers 
were "not properly trained to understand LD and to work with students who had a LD". She described the following in regards to her relationship with teachers.

A lot of teachers they put you down ... they kind of think that you don't have a potential to do academic level courses or university level courses. I think they just see learning disability as a disability and not as you are differently abled. (Becky)

While not stating that her entire high school experience was negative, Becky described having a positive experience in comparison to her elementary and middle school. She also acknowledged the contribution of her special education teacher on her personality:

My Special Ed. teacher told me "you can have a very high IQ or sometimes you have have a really low IQ with learning disability". It doesn't necessarily mean that you are stupid. I think it gave me more confidence. (Becky)

Hannah described that her experience with her teachers in faith-based high school varied substantially as some teachers were more supportive than others. She described two distinct experiences that have struck a chord for her from her high school days. She shared one prominent memory of a positive experience with her favourite teacher; Grade11 Math teacher as follows:

... the teacher had me like teach the class and then I went to do the test, and I pretty much got like two right. Like two marks right out of the whole thing, and the teacher was like 'ok what happened?' He is like, 'I don't understand. I know that you know this, I saw that you demonstrated ... What's going on?' So then, I told him about it [LD]. So he's like, 'Why didn't you say anything? Here let's work with it'. And so he was supportive, very understanding of it and I did my tests in a separate room, and even some questions he would read out loud. (Hannah)

She further described that her school experience or access to accommodations really depended on her teachers. She noted that some of the teachers would "just not care or respond" to the students' needs.

Claudia described her relationship with teachers in her private high school as "Good. It was always really good". Further she stated, "We were like on a first name basis with the 
teachers and you could walk into the principal's office if you had an issue and it was always that comfortable environment." Further she clarified that if she had trouble with an assignment, her teachers would always be there to help her or to answer any questions. She stated having a "lot of support ... which was good [and] was needed”. In regards to applying for university, Claudia replied by stating that some of her teacher motivated her to apply, and that she continues to have good talks with a few of them presently.

....and it's good to see them ... Like they knew I was capable. We were so close but that was part of the environment of the school. It's not like they are going to be rude to me just because I skip class a lot I guess. I think that's cuz of the environment that I was in. It was embedded that everyone has issues or whatever. (Claudia)

It is very interesting to note that Claudia's experience in a private high school contrasted greatly with that of Andrea, Becky and Hannah's experience. While Andrea, Becky and Hannah described their abilities being questioned or discredited by their teachers, Claudia had the comfort of attaining healthy education; where the teachers believed in her success.

\section{At Postsecondary Institutions...}

The path of achieving post-secondary education varied between the participants. It should be noted that while Andrea and Claudia pursued university education upon completion of their high school diploma; Becky received college education prior to her admission in university. Further, although Hannah was registered in a university upon completion of her high school education, she decided to pursue college education after her $1^{\text {st }}$ year at the university.

With her entry into university after completing her high school education, Andrea explained that her primary and secondary school experiences impacted her self-esteem negatively. She stated, "[the] internal anxiety I had and the lack of confidence I had, I went through hell in post-secondary because I didn't believe in myself." In terms of accommodations, Andrea and Becky both seemed pleased with their postsecondary experience. Andrea stated 
going to the same university for her undergraduate and graduate education. She described that their access centre was "really supportive" and that from her experience "the professors have been amazing”. Similarly, Becky also appreciated the accommodations provided to her during her college and university education.

I felt like in university and college there is so much more accommodation than when I was in middle school, high school and elementary school. There was so much more resources I can go and get help from on my own. For example when I was in high school I had to tell my Special Ed. teacher 'Oh can you help me edit this'. In university or college I can do that myself, with like assistance through programs I can download or from services from school stuff like that ... I am getting extra time for essays and assignments. Having a recorder for my lectures and stuff. (Becky)

Hannah's postsecondary experience is very interesting as she decided to reroute her path due to number of factors including high tuition fee, personal commitments and lack of interest in the undergraduate program she was enrolled into after her high school graduation.

One of my sisters who is older than me she is a single mom with 2 young kids. So I was trying to help her financially as well. So I stopped going to university. And I went to college. And cuz I thought, very wrongly that college is less work. College is way more work than university but it costs a lot less... So I was working 2 jobs and going to college and sending money to my sister and two kids. (Hannah)

Hannah's switch from university to college displays her strength as she paved her way while helping not just herself but also her sister. Further, she described completing three college diplomas and subsequently enrolling into an undergraduate program within a university which she was currently pursuing.

In regards to her undergraduate experience, Claudia described that similar to her primary and secondary school education, her undergraduate "program was small too [with] 60-80 kids in each year." Also, Claudia mentioned that she utilized her accommodations only sometimes, depending on her need and situations. Further, Claudia presented that she wasn't prepared to learn with dedication during her undergraduate degree. Apart from entering into a new academic 
environment of university life, Claudia was also diagnosed with an anxiety disorder in her second year. She stated, "that changed everything [as] I was panicking all the time". Further, she described that it was a difficult phase in her life as she felt overwhelmed and anxious about issues that hadn't concerned her prior to being diagnosed. However, she noted reaching out to get help from counsellors and briefly using medications for anxiety. She explained that her school education equipped her with knowledge about coping mechanisms such as mindfulness. She utilized techniques like solving puzzles to mentally stimulate herself while taking a break to help herself through the difficult time. Thus, she was able to find ways to cope with her LD and anxiety.

Claudia noted that the process of being admitted with the students with disabilities was a "big pain" which made her anxious in her graduate and undergraduate schools. She described the long wait list to schedule an appointment with an advisor to discuss accommodations was stressful. Further, she noted, "But I don't think it affected me as much. But I think that's because I wasn't trying as much ... I tried when I had to. But when I didn't, it was fine.” Claudia, further reflected on her undergraduate experience, “like in my university I didn't like it in my undergrad. It's just too much, too much going on and I would never want to teach a class like that". It can be noted, her experience significantly varied from her K-12 schooling in regards to class size, closeness with her educators and the process to gain accommodations. Thus, the addition of anxiety as interference in studies significantly impacted Claudia. Further, this is in contrast to the experience that Andrea, Becky and Hannah described as they appreciated the resources and support they received in post-secondary education while comparing it against their primary and secondary school education. 


\section{Relationships in Postsecondary...}

Andrea stated that she has had a good experience with professors. She mentioned that the professors have been supportive and accommodating.

I think I am fortunate to be at [school name] and in the [helping profession] program. Because I feel, you are so comfortable. Like I never felt so comfortable speaking about it in a very non-judgmental environment ... [with] the professors I have no problem. Like, I have had professors who have sat down with me, and tried to help me edit the papers or what not. So, it has been a really good experience and I feel like they get it. They reallyreally get it. (Andrea)

Alternatively, Andrea also described having a negative experience with a professor in her undergraduate program. She stated that the professor did not want to accommodate her, as he or she believed that Andrea "was at an advantage from the other students". Whereas Becky described that although there wasn't a close relationship with the professors as she only sees them during lectures, she finds that her relationship with them is "pretty good". She described feeling at ease when professors make class announcements to provide information for students to obtain accommodations.

... it was soooo, it was really helpful. It gave me so much more confidence and I did so much better I felt, and even professors they would mention it on the first day of the class. They would say any students with learning disabilities you can go to [Access Centre Name] ... and so I felt like, you are more aware. Professors also made aware to students about how to get help. (Becky)

Becky had a difficult experience of being bullied and feeling isolated in her elementary

and middle school education. However, she described her relationship with peers in a postsecondary setting as follows:

[Relationship with peers was] much better. Obviously now I am in the lecture room with my accommodations with me. And I didn't have that in middle school and high school right. I was taken away. So, I found that my relationship in high school and also in university is much better as I am there with my peers. (Becky) 
Hannah described that in the undergraduate university that she was at for a year after her high school graduation, she did not find a pleasant relationship with her professors. She stated "the professors just don't care [in that university]... not even if you have a disability ... if you have a normal question about what they are saying, they will shoot people down in class [saying] we don't accept questions." However, Hannah described her journey becoming positive as she studied through her college diplomas.

...just the professors wanted you to do a good job because it reflects on them. But they would be encouraging about it. They didn't put people down. They were like, 'ok let's do this again' or 'ok if a lot of people don't get it then obviously I am explaining it wrong. So I am going to explain it again in a different way.' Like they, it was not at all pressurized [laughs]. I graduated with a 97 average. (Hannah)

With her positive experience at colleges, Hannah undertook undergraduate studies at university level. She currently described her experience with professors as "mostly positive". ...I am taking families course and this professor does not allow laptops in the class. And she actually like I was in class and there were only 2 other people that were in class at that time. When I had my laptop open already, and so she told me, 'Oh so just so you know, I don't let people use their laptops' and right away I said, 'I have dyslexia and I have a really hard time taking notes on paper. And she said, 'Well do you have a paper from, because you have to get a certification from the resource centre" And I said, 'No, but I am more than happy to talk to you about why I don't'. She said, 'No it's ok you can use your laptop'. So, I was like 'Thank you'. (Hannah)

Hannah further described that the high cost of a psycho-educational assessment makes it harder for her to be accommodated. She noted that students who receive OSAP are entitled to get help from the office. However, she explained that for students like herself, who may not be taking OSAP loan but aren't financially "rich", it becomes a challenge as they may not be able to access accommodations for their LDs.

Claudia went to university immediately upon graduation from secondary school. She described having a good relationship with professors although she wasn't too close to them. She stated, "If I had some trouble, so I would always email professors ... and they were helpful or I 
would see them, which was great". Further, Claudia described her accommodations at undergraduate level were mostly provided for exams, which she felt content about. She stated approaching her professors with questions or help for assignments without having to disclose her LD. Claudia explained having had a good experience with most of her professors. However, last semester of her graduate program, she described having difficulty in regards to being accommodated by a professor. Claudia described that she was required to have an accommodation of one extra week to complete her course paper. However, the professor was not willing to give an extra week. Claudia described feeling anxious as she needed extra time, and had to get her liaison from the disability office involved in the process which still did not help, "because ultimately it's up to the professor but the professor was like, 'I have all these other papers to mark' ... it was just a very stressful process but it didn't need to be. And I found her very unaccommodating." In regards to her graduate school experience Claudia further explains that being in a program that had 20 students, it has helped her as she described, “ . .. like here I am talking to my teachers, professors all the time. So they know everything and work to whatever I want to tell them. But they are willing to help because there is 20 of us in the whole program."

Thus, it seems that most of the postsecondary experiences have been positive for the participants. However, the participants continued to face some societal issues in regards to their LD in post-secondary institutions. As Claudia notes, that "ultimately it's up to the professors to decide", this hierarchy between educators and students could stress students with LDs when they require the professors to support them through academic difficulty. Considering the importance of educators or professors' perception about LDs; Andrea described her experience as a graduate 
student of a helping profession as "even better" in comparison to that of undergraduate level. She stated:

They don't even want accommodations [form]; like, I made the accommodations form, I went to one professor because ... when I re-entered to do graduate school ... it was about that time I needed to do another assessment but my program was only an year long. And by the time that I did assessment the program would be pretty much done. I would have probably got the assessment by March. So, there is a discrepancy there. So the professors didn't really want the accommodations forms. They were just like, 'just let us know what you need'... they were great actually, just ok 'ok no problem'. (Andrea)

Andrea's experience of graduate school appears to be significantly positive. She also described feeling comfortable with the professors who she believed was very understanding of her challenges with learning and supported her throughout.

\section{Reflecting Back...}

All participants were asked to reflect back to their journey at the end of the interview.

Many of them were already reflecting throughout the interview as they talked about their past experiences and how it has affected them. For instance, Andrea described that before she would think she is "doomed". However her perception about her LD has significantly changed over the years as she explains:

Now I look at it as a label. Before I looked at it as you are impaired, you have a deficit, it's biological, you can't do nothing about it, tough luck, you know. But now, it's like no this is socially constructed, this is from I would say from when I first got diagnosed till now. Graduate school is more open about it but now I see that I have taken on this deficit label and it's impacted me ... and I have to be more aware of how that label controls my identity. Because it still does ... but I don't look at it as you know, I am unable or I am stupid, or you know. (Andrea)

Andrea reflected at her secondary school experience as follows:

"I was taught to believe that I couldn't. But here I am now. But I had to go through all these things, like issues with my confidence to be where I am right now. And I had to resist them. But that impacted me. This pisses me off. (Andrea) 
The impact of her school experience prior to post-secondary education has definitely

shaped Andrea's self-perception. Although she now realizes that her label has been placed by the society, she described:

...but sometimes, like there are still times in my head where I am like 'Oh God this is still hard!' or 'Can you really do it?' So these are the moments when you know that label really impacts me. Umm, even after understanding what it meant and going through all this. So there is still you know, still that shame, I guess shame there. But then I am constantly challenging myself. umm and trying. But it still impacts me. (Andrea)

Although the label continues to affect Andrea, she described feeling "stronger" through her experiences. She states, "no one should go through this, but I am thankful that I went through that because it's made me the person I am right now. And to fight for, and it made me more passionate about this issue." Further, she described her constant resistance throughout the journey and how she feels about it now.

...I almost feel like a survivor of the system. Like wow, I went through all that and I made it, and look. I almost wanted to go back to high school and be like 'look, I rocked my undergrad! I was a straight A student, high GPA. And I am rocking graduate school. You told me I couldn't, and here I am'. (Andrea)

Becky described her overall journey as such:

Honestly, [I] don't take it as a bad thing. I just learn differently right. But I felt that in elementary school and middle schools they don't take like that. It is seen more as a negative thing. Like I used to be like why the hell, why do I have this? Because I was always put down and I wasn't given proper accommodations and stuff like that. I was always bullied cuz of that, and I was always taken away and was isolated. So I was not too happy with what I had before in elementary school and middle school, I was not too happy of the fact that I had a learning disability. But in high school and in college and university I felt more comfortable with it. I was more like controlled, about when I can get help and stuff. (Becky)

Hannah described her experience as slowly becoming positive over the years. While initially she described frustration for not being accommodated in high school, and being a part of a highly competitive school, she noted that: 
... I just internalized it. Well, maybe just I'm just stupid or maybe this is my problem so I have to deal with it or they don't want to help me, no one wants to help me. Like, I just got really down on myself because of very different responses throughout my years of dealing with it. That I kind of begun to just take it all on myself (Hannah)

However, Hannah noted that her experiences have taught her, "They [LDs and the related experiences] are just like obstacles in the way. They are not who you are. It doesn't define you; it's just a part of the road." Further, her positive experience of being in college helped her build confidence, which is a driving force for her to be currently pursuing education as well.

Claudia associated LD with "diversity" where she stated it was part of human nature since we all learn differently. Further, she reflected back on her own experience with LD "I didn't really feel any different until I was older. Like until I realized what I needed to do to kind of help myself. Because I always weaseled my way around things." She explained that school seemed hardest for her in her undergraduate studies, and that it continues to be a struggle in her current graduate studies since it takes her "ten times longer to read an article". She affirms that she needs to keep herself motivated to complete school work, but believes that she is getting better at it. She stated feeling mature and having a better understanding of her LD upon completing her undergraduate studies. By having the challenge of LD she noted it has made her more accepting where she can relate to people. She explained feeling comfortable with her ADD and Anxiety as she stated "I would not take away my ADD, maybe I would take away my anxiety because I don't like it ... [but] it makes you unique. And I am ok with that." Claudia, also reflected on her experience while noting that she is "lucky" as she states:

Because I think if $i$ was in the [mainstream] system, I would be, sometimes I think I would have been some number you know. I might have failed or I might have been able to adapt which I would have possibly through experience ... I could never even imagine being with 30 kids in a class. Like in my university I didn't like it in my undergrad. It's just too much, too much going on. And I would never want to teach a class like that either. I don't think. But at the same time, it might have benefited me in terms of being 
able to meet people and being able to get used to that real world environment. Rather than my little bubble that I was used to. But I think that bubble saved me. (Claudia)

\section{Where Do I Belong?}

Andrea explained her resistance against the vocational program in Grade 9.

Then there is that stigma; they are not smart enough to go to university, or whatever it is right. But yeah, a lot of self-advocacy. That was kinda, I had a lot of attitude about it. Like I wasn't like a puzz or anything, 'this is not happening, I don't know why you think I need to be here [vocational program]'. (Andrea)

It can be articulated from above, that Andrea did not feel that she belonged within the vocational program class. By communicating the teachers who placed her within the program, she was able to resist the force of being placed in a school that would deprive her of the opportunity to gain college or university education in future. Also, Becky derived that vocational program was "not for me" as also resisted and switched back into the mainstream classroom.

Hannah on the other hand, described her experience at the religious high school where she was sent against her will by her mother:

umm just the teachers were very much like if you can't do it then that means that you shouldn't be at this level. And then, you don't belong here kind of thing, I think I was just really intimidated by it. Probably because of the dyslexia. I knew that it was the school that held people to a higher accountability. Umm and I knew they were-much-muchmuch more strict and I just thought associated it with smart people go there and with this disability a lot of time I had a lot of insecurities about ok I am good in this area, but I know I am terrible in other areas. So I kind of lumped it into I am not smart. So I don't belong there. (Hannah)

While Andrea and Becky both described feeling that they didn't belong at the vocational program due to associated negative labeling, Claudia experienced a variation of this experience. By being placed in a highly competitive and strict religious school, Claudia compared herself to the pupils prior to entering into the education system. Her dissociation from the characteristics of the students who "belonged" at that competitive school; students who were smart; she labeled herself as "not smart" due to her LD. 


\section{Feeling Ok}

In order for students with a LD to attain accommodations, it is important for them to first acknowledge their LD. Andrea stated that towards the end of grade 11, when she began to actively pursue university education; she "accepted it" and by conceptualizing that that her LD did not define her intellectual ability, she described "doing much better". Andrea described that her university experience significantly impacted her positively.

I never felt like someone, people were discriminating against me, or I never felt different. Actually, it helped me being in the program, [of a helping profession] it helped me be ok with that label. Be ok, with my learning disability. (Andrea)

Thus, her choice of study helped shape Andrea's experience and personality positively, as she learnt to feel comfortable and accepted her LD. The experiences in schooling prior to postsecondary education however still left an impact on her, while her university education helped her heal.

Becky began to feel comfortable after she started college. By being given the accommodations while she continued to be placed with her peers, Becky felt better about herself and her LD. Meanwhile, Claudia explained that her environment had a huge role to play in her acceptance and comfort with her LD.

... because it hasn't affected me at all, I am comfortable with it ... with my anxiety and ADD ... I think that has to do with whom I am too. Like I am open and I am blunt so I kind of tell people who I am upfront. Like just in case you know, [laughs] umm cuz it's a part of me. (Claudia)

It is interesting to note that Claudia's positive experience prior to her post-secondary education may have helped her build the personality that she describes as blunt and open. This helped to retain her confidence throughout her K-12 schooling, which she continues to currently endorse. 


\section{My Allies}

Andrea stated that her father has been very supportive of her. He also supported her to withdraw from the vocational school program in grade 9 . However, she stated that being a progressive individual he disagrees with the idea of her having a LD.

I think it came, so his brother had a disability, which is more of an intellectual disability right. So I guess he saw that stigma ... I think he is saying that because he wants me to succeed. Like he doesn't want it to create a barrier for me. In terms of my self-worth and my self-esteem right. (Andrea)

Becky stated that it was difficult for her to receive support from her parents since they failed to accept her diagnosis through primary schooling.

My parents don't believe in no such thing as learning disability. So it was kind of hard for them to understand. They thought it was just BS. and I think in the South Asian culture, you don't, I don't think they believe in stuff like that, so ... they all thought it was bullshit. They felt that I was pretending like, I could do much better than that. They had a lot more expectations so it was a lot of pressure on me. (Becky)

Through time, Becky explained that her parents have begun to "feel much better cuz they have seen [her] marks have improved, knowing that [she has] proper resources." However, Becky contained that her father is still trying to understand LDs. Also, she stated that if her parents were born or raised in Canada, they may have been able to better understand the concept of LD. Further, Becky noted that although she was unable to receive support from home, she had support from a friend while she was placed in a vocational program. The two of them studied together, and Becky stated that it became a little easier for her to go through the process of switching from vocational program to a mainstream schooling with her friend.

Hannah described that her sisters significantly supported her, "if it was a thing like writing a story or an essay, I got my older sisters to help me with the fixing, spelling or grammar there. So, that helped a lot." Also she stated having one friend in the high school with whom she was able to talk about her struggles. Further, she thought that her friend who was not diagnosed 
with a LD may have had one, as she had similar struggles to Hannah. While Hannah found support from her Math teacher in high school, she also tried to help her friend with her learning by advocating for her.

And then, one time the teacher talked to me and I'm like 'Emily [name changed] needs helps too. I know she can do it'. He is like 'Ok. Well, have her talk to me. If she doesn't talk to me I can't help'. So, I convinced her, I went with her one day after school and after that we got to do our tests in the hallway together which showed a lot of trust on his part [laughs] like we didn't talk out loud. We both would just sit out in the hall. That was something that it was a lot better having someone else in it with you kind of thing. So yeah she was sympathetic to not getting the best grades and everything. So for us like grades or anything like that was never a topic really. Unless one of us got a bad grade, we were sympathetic to each other about it. So no-judgement or anything. It was more understanding. It would have been much more difficult if she wasn't there. (Hannah)

Hannah was able to find support and non-judgement through her friendship. Meanwhile,

Claudia stated that she always had a strong support system of her family and friends. Since two of her good friends from childhood also have ADD, she found it to be very helpful for her. Further she stated, "You accept people for who you are I guess. But because I didn't think anything of it [LD], everything was fine and they knew that everything was fine". By having individuals in her life that supported her and made her feel at ease through her challenges with LD, Claudia was able to discuss with them about her difficulty with learning. Moreover, she did not experience being excluded, "stepped down" or pressurized by educators, peers or family members as they helped create a positive and nurturing environment for her.

\section{Cuz Succeeding is a Possibility...}

Some of the strengths and strategies that have helped the participants to counter difficulties in their academia will be discussed in this section. Andrea described that through elementary, middle school and high school education self-advocacy and resistance were key strategies for her success. "Because of that one move I made in my life, of self-advocacy of going into a regular high school, going through whatever i went through ... now I am at a 
graduate school.” Andrea noted through her experiences, “... cuz succeeding is a possibility.

Before it wasn't a possibility. I just went through it hoping. But now it's a complete possibility. You just have to know how to manoeuvre." (Andrea)

Becky stated that her major motivator to pursuing college and university education was "Definitely those teachers putting me down. It has definitely motivated me to turn those discouragements and make them into motivations." By having a positive outlook amidst the challenges of being told by teachers that she is not capable enough, Becky became determined as she stated thinking, "You know what, I can do this, and I will show you! I can!” Becky described being told by teachers in her middle school and high school that she will not be able to make it to university. However, she described "But then when I graduated from college and when I got my mark, then I thought maybe I can right." Thus, her college diploma helped her build confidence within herself, while she undertook the mission to pursue university education. Also Hannah described that through her college diplomas she gained confidence to pursue university education.

And I think the best thing for me, in terms of why I feel like confident enough to be in university now is because of that program I was in. It was all on computers. And I had developed such a good relationship with the professor and with the people in that school that it just set a positive, it erased the negative tone and set a positive tone for education going forward. So it was really inspirational. (Hannah)

Further, Becky stated, "I think as a student your job should be to be like to where to find the stuff and who to speak to." She spoke fondly of being helped by the resource centre through resources like pamphlets and by connecting her with a learning strategist that provided plentiful resources to her. The learning strategist also directed Becky to technician who helped her with attaining software to help with her accommodations for LD. 
Claudia described that she managed her LD by learning to find various methods to help her study. She connected with the specialist at schools to find learning strategies to help. Further, she stated using "easy way out" of studying by looking up online notes for English books or by asking other classmates any questions she had about a topic. Claudia's experience of volunteering and working also helped her to pursue university she explained, as it motivated her and also added to her credentials. Other ways that have helped Claudia manage her LD include, changing her study strategies where instead of fixating on a problem she has learnt to take a break and then come back to the issue after. Claudia described that having a change in environment such as working from home or library also sometimes helped her. She stated, "I am kind of aware more of what I don't like. I will work on something else when I get stuck on assignments whereas before I could only do one thing at once."

Claudia described that her openness to trying new methods and strategies has helped her succeed over her LD. Further she described employing a "process of elimination" where she would see counsellors to get support when needed. She describes being offered a list of strategies from them when she is having trouble with something. Further, she would also talk to her friends about the strategies so they can discuss it's applicability together, "they would be like, 'yeah that works for me' and I will be like, 'Ok I'll try it'. Try it if it works, and if it doesn't then it doesn't." Also determination to succeed and strategizing her study is a key where Claudia describes:

Because I know, I will wake up at 6am because I know I have to be at the library for 12 hours even though I might only study for 5. But I know it takes me 3 hours to organize my thoughts or finally get into the mode. Like, I know I have to do that. So that's the kind of stuff that I will do ... because it takes me longer ... I couldn't pace myself with the same time as my friends but I think i am ok with that. It's just who I am. I have accepted that. (Claudia)

Similar to Claudia, Hannah also described the importance of organization skills to succeed with her LD. She stated that since high school she had begun to practice and apply 
organization skills to help support her academics. Currently, while she was taking 6 courses this semester at the university, she relied heavily on scheduling and maintaining notes about her progress. During the interview she took out her agenda to see through her planned tasks and schedule.

Apart from self-advocacy and resistance through K-12, Andrea stated that connecting to her professors was an important strategy that helped her in the post-secondary education. Also, Claudia described the same, "I am an advocate. So, anytime I had an issue I would always say, this and this is what is going on, this is what i need from you, and what else can you give me." 


\section{CHAPTER 6. ANALYSIS}

Through the study, I noticed that the challenges faced by students with LDs are two pronged. The first challenge is in regards to finding strategies or accommodations to help in their learning. From the study, it seems apparent that the students found ways to accommodate their LD. All the participants were able to find ways to accommodate themselves through different forms of schooling and were able to successfully pursue post-secondary university education. Claudia discussed her LD with counsellors and friends to find possible ways to help her with studying. Some of these strategies included: taking breaks, changing her learning space and being determined to spend long hours at the library to get into the "study mode". Becky also found ways to accommodate her LD by using software programs for educational purposes. Hannah accommodated for her LD by using organizational and time management skills as her weapons of success. Whereas, Andrea and Becky noted that connecting with educators and the access centre helped them accommodate their LDs.

Since the participants attained their K-12 education in three different school systems within Ontario, public school, private school and religious school, their experiences were striking and assorted. Having studied in private schools, Claudia stated that she was in a "bubble" through her K-12 that kept her away from the "real world" and "saved her". It is interesting to note the use of words by Claudia, as she implies that her education was not a part of the real world since she did not feel marginalized or stigmatized due to her LD at school. Further, while speaking about her experiences Claudia stated that she "never had people say anything to [her] ... [and she] never had any bad experiences really" which she could remember. In contrast to this, Andrea and Becky went to public schools, while Hannah went to a faith- based school. These three participants noted marginalization and internalization of oppression during their 
school period. In the following analysis, I will attempt to analyse the experiences of the participants while discerning the impact of power, privilege and oppression on students with LDs.

As discussed before, all the study participants were able to manage their LD and were able to gain academic success. Moreover, Andrea and Becky did not describe having issues in obtaining accommodations. Andrea suggested; "Well, it [accommodation] was given to me. Like it was pretty easy. They wanted to do it more than I wanted it. Because I didn't want it." It seems that getting accommodations for her LD was not an issue for Andrea. However, when she utilized these accommodations as a student, she was exposed to social stigma and exclusion which affected her self-esteem negatively. It was more difficult for the students to counter the social implications of having a LD rather than their academic challenges. Similar to Andrea's experience; Becky also found that by taking the accommodations she felt "different". Through the social model of disability it can be noted that disability as experienced by Andrea and Becky were related to social reactions or barriers to their progress (Oliver, 1990). Due to the fear of discrimination, exclusion and marginalization, the participants refrained from utilizing the resources for academic support. Thus, it would have been easier for the participants had there not been marginalization or stigma experienced while they received support in an inclusive classroom environment.

The social impact of LD on the experiences held by students troubled them as they used words as lack of self-esteem/self-worth/confidence (Andrea, Becky, Hannah), shame (Andrea), frustration (Hannah), awkwardness (Becky) and feeling different (Becky, Andrea). On being placed in a segregated class in elementary school Andrea noted, "and that was when it reallyreally hit me, that I knew there was something different about me. Maybe something wrong, 
because I was put in a much smaller class right.” Becky further pointed out that her experiences being a student with LD in elementary and middle school classroom deprived her of the opportunity to maintain friendship with her peers. Through that period, she felt isolated and this significantly affected her as she experienced bullying and lack of peer support. This duly notes the impact of social reactions or stigma that decreases the student's participation due to exclusion (Oliver, 1990). Students actively or passively tried to mitigate these effects by covering their LDs and trying to conform to their classmates (Goffman, 1963; Jone \& Corrigan, 2014). As Andrea stated, that while she was offered accommodations in elementary school she reacted as, "Like even when they would try to pull me out of the class, I would be like "No I don't even want your help". I was very like "No, I don't want this. Go away." While explaining her high school experience, she stated:

Like in high school for some reason I moved so much. So I was in one high school in grade 9 and then i moved to another high school in grade 10. And for some reason, I completely got lost and nobody really kept track of the fact that I had a learning disability. It was really odd. I didn't care. I was like 'oh yeah' [excited tone]. So I basically, went through all of high school not getting any assistance and then, obviously I did not do so well. (Andrea)

Also, Andrea tried to conceal her LD by resisting the label by deciding to not selfidentify her LD in high school. While her attempt helped her to feel better about not feeling marginalized, with lack of support she stated doing poorly through grade 9 and 11 . Thus, in order to receive the supports she had to approach her counsellor and identify herself as a student with a LD. These accommodations helped her to pursue university education; however her experiences as a student who received these accommodations were bitter. Similarly, Hannah kept her LD as confidential from her teachers in high school.

They were very strict and they were just very 'if you can't do it at this level, then you are a bad person.' So it's like you are stupid and you are a bad person, and you are, they just add so many different psychological problems to the issue. (Hannah) 
She did not want to be judged by her teachers at her school as a "stupid and bad" person.

Thus, often times Hannah manoeuvred through her high school without gaining accommodations that could have helped her. Further, Hannah and Andrea explained concealing their LDs from their peers with the fear of being judged. Hannah noted;

I would see them as being judgemental towards other people ... and she (a girl from the group) took actually a lot of basic courses, and so whenever she wasn't around they would make fun of her for that. So, like just hearing that happen, I just didn't want to add to the talking (laughs). (Hannah)

In order to conform to her social group, Hannah used her hidden LD to help her. She joined in the chats about LDs, as she recognized that by disclosing her LD to her peers she would be talked about in a negative manner by them. Through the concealment of LD, it can be noted that Hannah, Becky and Andrea felt stigmatized and constantly worried about being judged for their LD (Goffman, 1963). However, in a striking contrast, Hannah experienced the hidden quality of her LD to be negative for her during an interaction with her grade 9 English teacher which she clearly remembered.

I talked to her about it because I didn't do that well on a test. And then she was like, 'What's going on? Why didn't you study? You need to study!' But I said, 'I do study, I do try." And she was just like, 'well you know you are not.' And I would be like, 'Yes I am' [laughs]. So well that went on and then I got frustrated. So I said 'I am dyslexic. I have problems when it comes to writing things out and all this stress of having to do a test makes is a lot worse'. And then she was like, 'Well you have never talked to us about this. You are lying!' I am like, 'No i am not' [laughs] ... that's always something that stayed with me. Just because her response was ... not nice, not helpful. It was very negative ... just fails you at school. (Hannah)

The above experience of Hannah is troubling in nature, as her teacher discredits her LD that is hidden. Since Hannah also described that her grades were pretty good, but she struggled with learning; it seems likely that her teacher could not place the societal stereotypes that are associated with students with LDs within Hannah. Thus, Hannah was negatively impacted by 
this. It is interesting to note that Hannah experienced both the positive and negative attributes of her hidden LD. Being hidden in nature, Hannah had the ability to conceal her LD amidst her friends as Goffman (1963) notes. However, it was difficult and distressing for her when her teacher disregarded her LD due to its hidden nature.

The experiences of Andrea and Becky, who were both in the public school system raises concerns about the structure of the education system. By utilizing streams such as vocational, academic or applied, students are categorized by educators. Using, testing as a mode to evaluate the knowledge held by the students, they are placed within a system of hierarchy. As CTE asserts, this categorization is a form of cultural reproduction within the education system that framed from the contributions of a hidden curriculum to maintain capitalist social order (Morrow \& Torres, 1994). By placing students into categories, their future is already established by the educators. The students experienced disability through the exclusion from social and educational disadvantages inflicted by the mainstream education system on them (Prince, 2009). Hannah notes in regards to the courses and streaming:

But ultimately the school has the final say; the teachers have the final say. So right in grade 9 if they stick you in a basic class, pretty much that was saying you are not going to university. So, it's like you could know right off the bat if I am going to go to university or am I going to go to college or not go at all. (Hannah)

Although Hannah studied in the education system that contained the curriculum of Ontario Academic Credit (OACs) that consisted of Grade 13 within Ontario, this categorization still exists using different names such as academic, applied and vocational streams. Thus, the practice of dividing students based on their academic performance or perception about their abilities would be a definite factor to hinder their success as explained by Wotherspoon (1998).

Further, as evident from the study findings, it can be noted that if Becky and Andrea had not opposed by saying "NO" to the categorization in their high schools, they would have not 
been able to attain college or university level prerequisites for their higher education. While advocating for equality within the education system as described by Demaine (2003) the students opposed the mainstream ideology of maintaining power relations through categorization and streaming. Their resistance prevented them from heading towards academic failure of not being able to continue higher education (Giroux, 1983). Had this not been conducted, the academic and personal growth of Becky and Andrea would have been stunted. Thus, Becky and Andrea applied resistance to oppose their categorization as students with LDs in vocational programs. As Becky stated, she didn't mind having a LD through her K-12. However, she didn't like being excluded or segregated into another classroom or school to help with her LD. This explicit categorization impacts academic growth and self-perception of the students.

The prominence of the Medical Model of Disability operating within the public education system can also be viewed from the participant's stories. Both Becky and Andrea noted discouraging words from their teachers in K-12 education. As Becky states, "teachers underestimate students and their abilities, bring you down...rather than considering them as students with different abilities they focus on disabilities". The medical discourse places the blame on the students as it highlights their deficits (Oliver, 1990). By placing labels such as "stupid" or by maintaining lack of hope for student success, the educators send a message to the students about their incapability to pursue college or university education. Educators play a major role in the development of the students. As noted by Wotherspoon (1998), students may begin to internalize these comments, which would eventually lead to a self-fulfilling prophecy. As Andrea stated, "I think it's [lack of self-esteem or confidence] the biggest barrier for me it was. It wasn't even my learning. It [Learning] wasn't even my struggles." However, both Andrea 
and Becky, resisted not only the exclusionary practices within the school system, but also resisted internalizing the deficits as spoken by their teachers.

Further, the Andrea and Becky noted that the process of going through the psychoeducational assessments and attaining its results made them feel less-worthy. As the assessment process required the students to leave their class to perform testing with a psychologist during their school day, Andrea and Becky described feeling "different" and confused about what was happening. Since neither Becky nor Andrea was made aware about what it meant to have a LD, the students suggested that it was difficult for them to deal with the idea of having a LD. Also, the psycho-educational assessments further impacted their self-worth as Andrea noted, it listed deficits held by the students. Being ingrained in the medicalization of disability (Oliver, 1990), this process was stigmatizing for Andrea and Becky. Further, the students faced challenges when their families and ethnic communities disregarded the concept of LDs. Both the participants noted the stigma about their LDs in their families that did not allow them to discuss their challenges with their allies comfortably. Becky further stated, maybe if her parents were born or raised in Canada, or if they had been made aware about the challenges and resources for students with LDs; she would have found it to be very helpful during her challenging time at elementary, middle and high school.

Psycho-educational assessments help identify the needs of students to help accommodate their learning styles. However, the process of diagnosis should not be marginalizing as experienced by Andrea and Becky. As I reflect on Claudia's experience, I believe that it is possible to avoid marginalization through the process of diagnosis. Claudia was tested by psychologists outside of her school, and the process was explained to her by her mother. Claudia also felt comfortable with the process as she recognized it's applicability in helping her study, 
and she did not have to leave her regular classroom to do her testing. With support from her family, Claudia did not feel stigmatized about going through the psycho-educational assessment or about having a LD within her classroom. The environment of support and understanding, helped in fostering Claudia to become a strong self-advocate where she has always felt comfortable about her LD, and could speak openly about her LD without shying away from asking for resources to help her.

Through Claudia's school experience, it is interesting to note that the private school experience did not consist of her being marginalized through categorizations or streaming. Although, Claudia struggled with her own disability as she did poorly in middle and high school, and was involved in drinking, skipping classes; she noted that the teachers always assisted and encouraged her.

Like, I don't know we read a lot this year about teachers [in public schools] just giving like notions, they just judge them [students] and they don't care. And they don't have time for them. But it wasn't like that for us I think. (Claudia)

Without judgement from her teachers, Claudia's experience notes the absence of marginalization of students who have LDs in a private school setting. Claudia maintained that throughout her schooling she had ample support and encouragement from her teachers, "they had hope, so we had hope. And it works". By noting that the Medical Model of Disability did not operate during Claudia's schooling, she did not find herself being placed in exclusionary environments. This also helped her internally as she viewed LDs as a diversification of learning. Without feeling "different" from her peers, she was able to achieve a healthy learning experience. Further, the support from her teachers strengthened her self-esteem, and she felt proud of being accepted into university despite challenges from her LD. This is a definite 
contrast in the social experience of being a student with LD in a public or Faith-based school system as experienced by Andrea, Becky and Hannah.

In relation to the positive experience of Claudia as a student with LD, Claudia stated that although she did poorly and was a "troublemaker", her teachers did not judge or discourage her as a student with LD. She attributed this mainly to her privilege of being in a private school, where she stated, "I think, it's also cuz they, umm because we paid to go there so they had to".

This raises the issue of commodifying knowledge and schooling. As viewed through a CTE lens, it is clear that neoliberal values therefore act on education system where the privileged gain access to greater number of educational opportunities (Wotherspoon, 1998). Having the privilege to attain education from a private school, Claudia stated feeling "lucky" to not be a part of the "system" as she received help and support that was needed for her success. Meanwhile, her challenges with LD were in relation to the learning process, rather than the social implications of LD as experienced by Becky, Andrea or Hannah.

Having evaluated the experiences of the study participants and noting that it is possible to make the experiences less challenging for students with LDs, the next section will entail the implications and conclusion for this research. 


\section{CHAPTER 7. CONCLUSION}

I recognize that the participants interviewed in this study were "successful students" who were able to pursue post-secondary education while rebelling against mainstream notions of disability and privilege. As I analyzed the data, a question frequently came to me: Are these students battling against LD or against the social implications of LD?

In support of the the Social Model of Disability, it seems pertinent that although students may be challenged by their LD, accommodations and support decrease the prominence of these challenges. However, the social implications of being a "student with a LD" seem much more diabolic for these students as they experience marginalization and exclusion from their mainstream peers. The students in this study not only succeeded against their LD by adapting strategies to help them learn, but they also succeeded against the social norms that constricted their ability and progress. The participants in this study were able to successfully resist to the mainstreaming of education system. However, at a larger scale some students with LDs may not be able to resist to this mainstreaming due to their social context. Thus, it is important for us to further understand and modify the education system which stands to normalize differences in learning rather than pathologizing it.

Given the knowledge from the lived experiences of these participants, we must challenge the mainstream approach towards education and social constructs of learning. For instance, it is important to reconsider the practice of categorizing students into streams such as vocational programs and special education in the name of "accommodating" students. By determining the individual abilities of the student, and perhaps underestimating them, we limit the growth of the student. This may thereby defy the purpose of offering accommodations to these students. On this stance Andrea voiced her suggestions that educators should support students to "whatever 
[students] think they are worth" and by not undermining the ability of the students. It can be therefore inferred that solely having "accommodations" for students with LDs is not enough. There needs be more work done through research, evaluation and practice to provide "good support" to the students. Devoid of discrimination, educators and social workers should be assisting the growth of students while nurturing them with knowledge.

Salutin (2012), states that for students in the vocational streams within the Canadian education system, it is implied that they are at the end of their academic choices. Further, schools that provide specialized programs such as vocational programs focus on fragmentation as they segregate students, depriving them of an opportunity to interact with peers to stimulate their minds with different experiences, skills and knowledge held within the same classroom (Salutin, 2012). This fragmentation takes away the pressure from the system to improve the experiences of all students (Salutin, 2012). Through this study it was also noted that segregation has definite negative impacts on the students. However, due to the nature of this study and small sample size, the implication of this factor cannot be confirmed for a larger student population. Further, Becky noted that the special education classrooms helped her better understand the subject material although she felt excluded from her peers. Thus, rather than adopting a cookie-cutter approach of implementing inclusive or segregated programs to teach students, we must reflect on the learning needs and comfort of the student. Through any implemented teaching strategy, we must ensure as social workers to advocate for social justice within the education system. It is important for social workers to collaborate with teachers to assist in curriculum planning and to discuss ways that encourage and provide resources for students with LDs.

It can be viewed from the findings that the participants stated fairly positive experiences in university or college level education. As identified by Becky, at college and university she 
found many resources to support her learning which allowed her to perform well. Further, by having access to appropriate resources and positive experiences with professors in postsecondary settings Andrea, Becky and Hannah felt encouraged. It can be noted through this study that with proper accommodations, support from the educators, and with the determination to succeed, all the participants have been able to be create their success story. The participants achieved this success by not allowing LD to be a barrier in their progress: internally (doubting self-worth, selfesteem) and externally (vocational programs and special education classes). The participants described that their experiences with educators played an important role for them. Becky and Hannah described their K-12 experiences with teachers were mostly negative; however each of them was able to recall one positive experience. Becky explained that it fostered confidence within her when her special education teacher spoke to her about how LD does not signify that someone is "stupid" because an individual with a LD could either have a very high IQ or a very low IQ. Meanwhile, Hannah was able to receive encouragement and support from her grade 11 Math teacher. Further, Claudia described her relationship with her teachers in middle and high school while contrasting it with those of students in public schools, "It was good cuz they [teachers] still had hope, we still had hope. And it works". Andrea was unable to provide with positive experience with her K-12 teachers. I strongly feel that in our education system students should be able to recount more number of positive experiences with their teachers. 'Hope' from teachers shouldn't be a theme that occasionally appears within student-teacher interactions. I believe that by placing their confidence in students, educators can motivate students to excel academically while providing a healthy and nurturing learning environment.

Becky and Andrea described that it would have been helpful for them to have had their LD explained at an early age. Both the participants reflected back stating it would have helped to 
have LD defined in a different way rather than deficit, impairment or a negative attribute through elementary and middle school. As social workers it is important for us to be part of the process that redefines and constructs the meaning of LD. In this process, social workers who work at schools need to be fully involved in understanding the intrinsic and extrinsic ways oppression may operate within the school system for students with LDs. Social workers must raise awareness about LDs while simultaneously challenging stereotypes and discussing the microaggressions of disability related language and labels (Connor, 2013). Also it is important to develop informed policies at various levels: school, provincial and national levels to demand social justice and inclusion for people with LDs (Connor, 2013).

Through the analysis, it can be construed that students with LDs find themselves challenged by medical discourse and neoliberal values within the education system. As social workers, we are service providers and allies to individuals with LDs. It is important for us to work together so we can listen, acknowledge and work with clients and counteract the drowning of their critical voices in the midst of the larger belief system (Poole et al., 2012). Since disabilities are a societal characteristic (Stubblefield, 2007) it is important for us to challenge the society's perception about what constitutes as a disability. By treating a difference in learning or other modalities as a social restriction, rather than an individual flaw will create a society that is more inclusive and oriented towards social justice (Oliver, 1990). Further, as social workers we must work together with individuals with LDs and their support systems such as parents and service providers to counter the mainstream views about education. Becky suggested that it would have been helpful for her if her parents were aware about LD and relevant accommodations. She stated that if her parents were aware about LD earlier, she may have been able to gain support from them through her challenging times at school. I believe that social 
workers must therefore educate networks through outreach and community partnerships to develop a community wide understanding of LDs that is devoid of assumptions and stereotypes through literacy (Rosen, 2006). We can help to dismiss the ambiguity of LD while raising awareness within the society. This would help erase the negative notions or the language of "deficits" about LDs while we work towards creating a just society.

\section{Closing Remarks}

Wotherspoon (1989) explains silencing as, "a process through which particular kinds of social experiences and alternate voices are devalues, marginalized, or denied a place within educational practice" (p.87). I hope that this study can contribute towards breaking the silence about the educational experiences of students with LDs. In conclusion, I would like to refer to a quote by Linton (as cited in Sherry, 2004) that reads, "Society creates many of the problems disabled people experience and society has a responsibility to address them" (p.529). This resonates with my understanding of how as social workers and allies for individuals with LDs, we need to take a responsibility collectively to overcome these barriers that are created by us. By focusing on client's role restoration and strengths, Rosen (2006) explains that we need to recognize that stigma is a response to interlocking system of oppression caused by the tensions from ableism and capitalism within the society. We must endorse the socio-cultural and socio-political models of LDs to recognize that LDs are not stagnant but are dependent on social perceptions, beliefs and actions (Reid \& Valle, 2004). Thus, as social workers we must together work as allies of individuals with LDs, to alter social understanding and policies that are associated with LDs. I believe that by being actively involved in transforming the dominant discourse of LD, from Medical perspective that pathologizes disability to the Social Model of Disability, it is possible for us to encourage social justice and equity for individuals with LDs. 


\section{APPENDIX A}

Richa Sud (Last Modified: March 17, 2014)
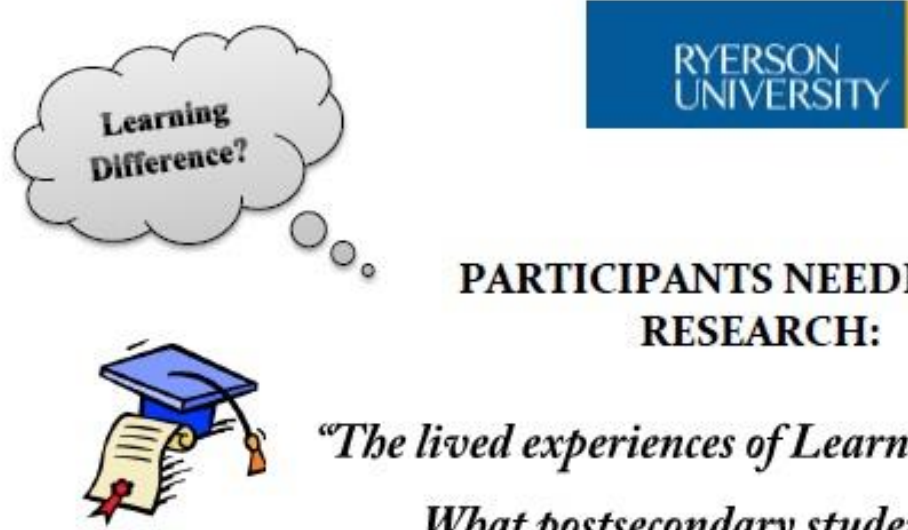

UNIVERSITY

PARTICIPANTS NEEDED FOR RESEARCH:

\section{"The lived experiences of Learning Disabilities: What postsecondary students tell us"}

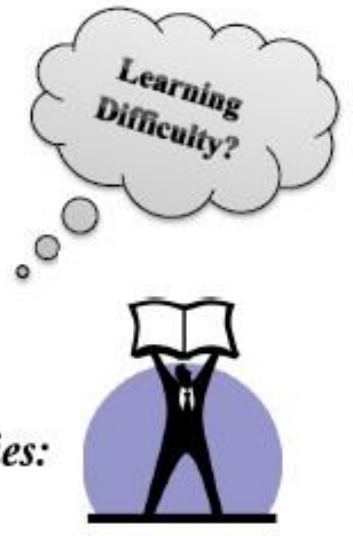

If you are you a current student in a college or a university with a Learning Disability; and are less than 30 years of age:

I invite you to participate in this study to share your experiences; in relation to your Learning Disability.

The research seeks to understand your experiences with LDs; and will draw resiliency factors, coping strategies, and resources from your experiences.

Your voluntary participation would involve an interview lasting 60-90 minutes with the researcher: a Social Work graduate student at Ryerson University.

I will provide public transportation costs for the study

For more information, or to volunteer for this study, please contact:

Richa Sud

School of Social Work

Contact Number: 416-979-5000 Ex: 4789

Email: richa.sud@ryerson.ca

This study has been reviewed by, and received ethics clearance by the Ryerson University Research Ethics Board.

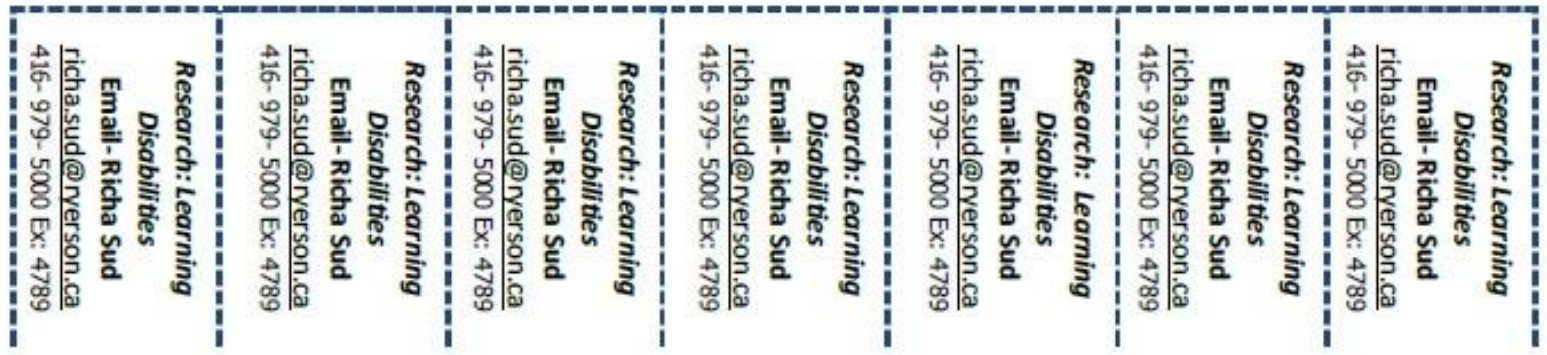




\section{APPENDIX B \\ Email Recruitment Script \\ Richa Sud, BSW; BSc. (Hon) \\ Masters Candidate in Social Work}

\section{Research Study: The lived experiences of Learning Disabilities: What postsecondary students tell us}

E-mail Subject line: Seeking students for a project on Learning Disabilities

I am a graduate student in the social work program at Ryerson University, and I am conducting a study named "The lived experiences of Learning Disabilities: What postsecondary students tell us".

The study aims to explore the experiences of students with Learning Disabilities (LDs), who are currently enrolled in a college or a university. Further, the study also aims to broaden the scope of literature in relation to students with LDs who belong to racialized backgrounds.

I hope to project the experiences of the postsecondary students with LDs by recognizing the challenges, coping strategies and resources that construct their experience. Further, I hope that the study could serve as a potential guide to encourage current secondary school students with LDs.

If you are a current postsecondary student with a learning disability; and are under 30 years of age; I invite you to participate in this study.

Your participation will comprise of an interview that will take 60-90 minutes and will be held in a setting that is convenient and confidential.

This study has been reviewed and approved by Ryerson University's Research Ethics Board.

Your participation in this study will be strictly confidential, and I will ensure to maintain the confidentiality of any shared information.

If you are interested in hearing more about the project or in participating please send me an email: richa.sud@ryerson.ca or contact me at: 416-979-5000 Ex: 4789

I would like to thank you in advance for your time and consideration. A one-time follow up reminder will be sent in a week.

Regards,

Richa Sud (BSW BSc.)

Masters Candidate in Social Work

School of Social Work

Ryerson University, Toronto Ontario

Email: richa.sud@ryerson.ca

Contact Number: 416-979-5000 Ex: 4789 


\section{APPENDIX C}

\section{TELEPHONE INTERVIEW SCRIPT}

Purpose: To confirm the eligibility of the participant and build researcher-participant rapport

\section{Script:}

Good Morning/ Good Evening,

My name is Richa, and I am a graduate social work student at Ryerson University. I am calling you in regards to your interest in participating for my research study about exploring the life experiences of students with learning disabilities. This research is being conducted as a requirement for the Master of Social Work program at Ryerson University.

I would like to provide you brief information about the study, and would like to ask you few questions to determine your suitability as a participant.

The research study is named,"The lived experiences of Learning Disabilities: What postsecondary students tell us" and it aims to explore the life experiences of students with Learning Disabilities (LDs) who are currently enrolled in a college or a university. The study will focus into various issues faced by students; such as stigma, and oppression in relevance to LDs. It will also seek to explore coping strategies used by students to overcome personal and social barriers due to their learning disability through their secondary school experience to successfully pursue postsecondary education. Further, the study will incorporate participants from various racialized backgrounds who have LDs, to explore their life experience.

Could you please confirm if you were identified to have a learning disability prior to your postsecondary education?

\section{YES NO}

Are you currently enrolled in a college or university?

YES NO

What is your current year of study? Current year of study:

For this study, I am looking to interview students who are under 31 years of age, to ensure that the experiences shared by the participants belong to a common timeframe. This would help understand the essence of experiences within the study participants.

Would you be able to provide your age for study purposes? Age:

*If the identified age is over 31 years: I thank you for taking the time to respond to the study. I apologize, but at this time the study seeks participants who are under 31 years of age for research 
purposes. However, I thank you once again, and wish you good luck with your future endeavours.

Since the study hopes to also explore the association of the learning disability experience with students who may belong to racialized backgrounds, could you please identify your race/ethnicity for the research purposes?

Race/ethnicity:

Considering the above information as provided by you, it seems likely that you are a suitable participant for the study. The study involves collecting and analysing experiences of students with learning disabilities. The participants will be interviewed about their experiences in relation to their secondary school experience and transition to college or university. This interview will last from 60-90 minutes.

In order to conduct the research study with your involvement, I would like to provide you with consent form that contains further details about the study and asks for your consent to be involved in the study.

Your participation in the study is completely voluntary and you will not be provided any compensation for it. However, public transportation costs to reach to-and-from the interview location for the study will be reimbursed by the researcher.

You will help to further enrich literature about learning disabilities. It will also be an experience for you to reflect back on your own experiences, challenges and strategies that have helped you succeed academically. Further, your experience will serve as a guide and inspiration for students with learning disabilities who aspire to pursue postsecondary education.

I thank you for taking the time to participate in the research. Your confidentiality will be preserved through the study and interviews will be held in pre-booked study rooms at either public library, Ryerson University library or any other suitable space convenient and comfortable to you.

Please provide your email address so I could email you the consent form. You could read the form and ask any questions about the study either before the interview via email, or on the day of the interview. Also you have the option to sign the consent form and send back the copy via email or bring along a signed copy with you at the time of the interview.

Email address:

You could respond back to the email with consent form to provide suitable days and times for doing an interview for the study. To confirm your interest in the study, I will follow up with you via a phone call in a week in an absence of email response from you.

Thank you once again for contributing to the research project. 


\section{APPENDIX D}

\section{RYERSON}

UNIVERSITY

\section{CONSENT TO PARTICIPATE IN RESEARCH}

\section{The lived experiences of Learning Disabilities: What postsecondary students tell us}

You are being invited to participate in a research study. Please read this Consent Form so that you understand what your participation will involve. Before you consent to participate, please ask any questions necessary to be sure you understand what your participation will involve.

\section{INVESTIGATORS}

This research study is being conducted by Richa Sud - Graduate student, from the School of Social Work at Ryerson University. The results of the study will contribute to the Major Research Project that will be completed by the Primacy Investigator (PI).

If you have any questions or concerns about the research, please feel free to contact:

Primary Investigator:

Richa Sud - Master of Social Work Candidate, Expected 2014

Email: richa.sud@ryerson.ca

Faculty Supervisor:

Susan Silver, PhD - Associate Professor, Ryerson School of Social Work

Email: ssilver@ryerson.ca

Phone Number: 4169795000 ext. 6216

\section{PURPOSE OF THE STUDY}

The study aims to explore the life experiences of students with Learning Disabilities (LDs) who are currently enrolled in a college or a university. The study will focus into various issues faced by students; such as stigma, and oppression in relevance to LDs. It will also seek to explore coping strategies used by students to successfully pursue postsecondary education; while they overcome personal and social barriers due to their learning disability through their secondary school experiences. Further, the study will incorporate participants from various racialized backgrounds who have LDs, to explore their life experience.

\section{DESCRIPTION OF THE STUDY AND YOUR PARTICIPATION}

If you volunteer to participate in this study, you will be asked to do the following things:

Upon your interest into the study, information about the study will be shared with you. Through a brief phone interview your eligibility for the study with be determined by collecting demographic information to confirm: identification of learning disability, current enrolment in postsecondary institution: Year of study, age and racial ethnicity. Once, it has been determined that you are suitable participant for the study, through mutual availability of you and the investigator a date, time and preferable location to conduct 
interview will be established. The interview will be held to preserve confidentiality, in pre-booked locations such as study rooms of public library or Ryerson University's library.

The interview will be held for 60-90 minutes and will comprise of questions to explore your personal and academic experience of having a learning disability. The questions would reflect your journey since being diagnosed with a learning disability, and how that label influenced your experiences in high school and postsecondary education. Example of interview question would be:

- Tell me how it feels to be a student with a learning disability in a secondary school classroom?

- Tell me about your relationship with teachers in high school and with your current professors?

- What factors influenced your decision to pursue postsecondary school?

The interview will be recorded on a digital voice recorder to permit transcribing of the experiences for data analysis. Further relevant themes will be derived during the analysis from the collective experience of the participants with LDs.

During the interview, you will be under no obligation to answer all the interview questions. At any time during the study, you are able to withdraw from the study devoid of any consequences.

A copy of the study results can be provided to you once the MRP has been completed. The identities of the participants will be held confidential, and you will only be recognized by a pseudonym. You have the option to request for a copy of the study results which can be provided to you either electronically via email or in person, as requested by you. Please provide your email address at the bottom of the consent form's last page to request study results.

\section{POTENTIAL RISKS AND DISCOMFORTS}

The potential risks and discomfort involved for you in this study are minimal. There is a possibility of psychological risk due to difficult emotional experiences that you may reflect upon during the interview.

You will have the option of choosing to share your personal life experiences with the investigator for research purposes. Further, you will be able to take a break anytime during the interview, or skip any question to suit your comfort. At any time during the research process, you will have the ability to discontinue you participation in the study. If you choose to discontinue, all interview data and the relevant information will be destroyed straightaway.

Further, your identity and participation in the study will be held confidential. The interviews will be transcribed using pseudonyms which will be chosen by you for the interview. The study data will only be accessible to the researcher. Therefore, the risk of your identity being revealed to peers, faculty or any other individuals will be held minimal.

\section{POTENTIAL BENEFITS TO PARTICIPANTS AND/OR TO SOCIETY}

The study will help broaden the scope of literature about learning disabilities in relation to students who belong to racialized backgrounds and are able to pursue higher education. Specifically the study will contribute to the field of social work.

You may not gain any direct benefit from participating in the study. You will have the opportunity to reflect back on your experiences. By drawing from your experiences, and recognizing the resiliency factors, coping strategies and resources that have helped you; I hope that the study could serve as a potential guide, and encourage current secondary school students with learning disabilities. 


\section{PAYMENT FOR PARTICIPATION}

You will not be paid to participate in this study. However, you will be reimbursed for any public transportation costs for participating in the study interview.

\section{CONFIDENTIALITY}

The interview will be conducted by the primary investigator who will also conduct data analysis and transcription of the interview. The information will be accessible only to the researcher. In a situation that requires the faculty supervisor to assist the primary investigator with the data analysis, the transcribed printed information may be shared with Dr. Susan Silver (Associate Professor, Ryerson University) with the use of pseudonyms or codes to conceal your identity. Thus, it would ensure confidentiality of information recorded.

The voice recordings will only be accessible to the primary investigator. All voice recordings and electronic copies of the interview will be deleted once they have been printed. The printed copy of the transcript will be stored in the locker present for social work graduate students for until the period of research. The transcribed information will be stored by the researcher for until and including December 2014 and will be discarded hereafter.

In the final report there will be no identifiable information provided. All information from the interview will be presented in the form of themes and quotes, not attributed to any individual.

\section{VOLUNTARY PARTICIPATION AND WITHDRAWAL}

Participation in this study is voluntary. You can choose whether to be in this study or not. If you volunteer to be in this study, you may withdraw at any time without consequences of any kind. If you choose to withdraw from this study you may also choose to withdraw your data from the study. You may also choose not to answer any question(s) and still remain in the study. Your choice of whether or not to participate will not influence your future relations with Ryerson University.

\section{QUESTIONS ABOUT THE STUDY}

If you have any questions about the research now, please ask. If you have questions later about the research, you may contact:

Richa Sud - Master of Social Work Candidate, Expected 2014

Email: richa.sud@ryerson.ca

Study Supervisor: Dr. Susan Silver

Phone Number: 416-979-5000 Ex 6216

Email: ssilver@ryerson.ca

This study has been reviewed by the Ryerson University Research Ethics Board. If you have questions regarding your rights as a research participant in this study, please contact:

Toni Fletcher, Research Ethics Coordinator

Research Ethics Board

Office of the Vice President, Research and Innovation

Ryerson University

350 Victoria Street

Toronto, Ontario M5B 2K3

416-979-5042 or toni.fletcher@ryerson.ca 


\section{SIGNATURE OF RESEARCH PARTICIPANT/LEGAL REPRESENTATIVE}

Your signature below indicates that you have read the information in this agreement and have had a chance to ask any questions you have about the study "Dissing Learning Disabilities" as described herein. Your questions have been answered to your satisfaction, and you agree to participate in this study. You have been given a copy of this form.

Name of Participant (please print)

Signature of Participant

Name of Legal Representative (if applicable)
Date

- As a study participant please sign below your consent to being audio-recorded for the research purposes:

Signature of Participant

- Please provide your email address if you would like to receive an electronic copy of the results of the study.

Participant's Email Address

Signature of Participant 


\section{Appendix E - Interview Guide}

\section{The lived experiences of Learning Disabilities: What postsecondary students tell us}

Preamble: Thank you for agreeing to be part of this research process. Before we start, I would like you to know that this interview will take approximately between 1 and 1.5 hours. I also want to assure you that everything you say here is confidential and that only I will have access to the information you provide, with the exception of my research supervisor. All identifying information will be removed from your transcript and a pseudonym will be used if you are quoted. Before we begin, I would like to ask your permission to record the interview. At any point during the interview, you may ask to stop the recording or take a break. You can also terminate the interview at any point if you feel any discomfort or you decide to change your mind about being part of this research study. Do you have any questions before we begin?

1. Tell me about the first time you became aware about your learning disability?

a. How old were you at that time?

b. What grade were you in?

c. Is there a memory that comes to mind?

d. Tell me what you felt about it?

2. Tell me how it feels to be a student with a learning disability through kindergarten to gr12 in a classroom?
a. Experience in regards to school work
b. Thoughts about education system
c. Relationship with peers
d. Relationship with teachers

3. Prior to enrolling in a college/university, what were your aspirations about your career?

a. What or who affected your thinking about career?

b. How did you come to the realization that you wanted to pursue college/university education?

4. What factors influenced your decision to pursue postsecondary school?
a. Parents
b. Personal strengths and strategies

5. Tell me about your experience as a university student with a Learning Disability? (Inc. Professors, accommodations)

6. What is it like to be a student with a learning disability and to also belong to a racialized background/ or an ethnic group?

a. Is there an instance you recall where learning disability and your race/ethnic community or practices were associated together?

b. Was it possible for you to discuss about your learning disability or experiences relevant to it with your ethnic community?

7. Tell me how you now perceive "learning disability" as?

a. What forms of challenges do you continue to face at college/university in regards to your learning disability?

b. How have you managed your learning disability at college/university? 


\section{References}

About the EQAO. (2013). EQAO: About EQAO. Retrieved from http://www.eqao.com/AboutEQAO/AboutEQAO.aspx?Lang=E

Apple, M. (1982). Education and Power. London: Routledge.

Arthur, A. R. (2003). The emotional lives of people with learning disability.British Journal of Learning Disabilities, 31(1), 25-30.

Baker, B. (2002). The hunt for disability: The new eugenics and the normalization of school children. The Teachers College Record, 104(4), 663-703.

Barga, N. K. (1996). Students with Learning Disabilities in Education Managing a Disability. Journal of learning disabilities, 29(4), 413-421.

Barnard-Brak, L., Lechtenberger, D., \& Lan, W. Y. (2010). Accommodation Strategies of College Students with Disabilities. Qualitative Report, 15(2), 411-429.

Byrne, M. M. (2001). Understanding life experiences through a phenomenological approach to research. AORN Journal, 73(4), 830-832

Caelli, K. (2001). Engaging with phenomenology: is it more of a challenge than it needs to be?. Qualitative Health Research, 11(2), 273-281.

Carrier, J. (1986). Learning disability: Social class and the construction of inequality in American education. New York, NY: Greenwood.

Chilisa, B. (2012). Decolonizing the interview method. Research methods in question. In Indigenous research methodologies (pp. 73-96). Los Angeles: SAGE.

Cory, R. C. (2005). Identity, support and disclosure: Issues facing university students with invisible disabilities. (Doctoral dissertation). Retrieved from Google Scholar.

Cowen, S. E. (1988). Coping strategies of university students with learning disabilities. Journal of learning disabilities, 21(3), 161-164.

Creswell, J. W. (2007). Qualitative inquiry and research design: Choosing among five approaches. London: SAGE Publications.

Curtis, B., Livingstone, D., \& Smaller, H. (1992). Stacking the Deck: The Streaming of Working-Class Kids in Ontario Schools. Toronto: Our Schools/Our Selves Education Foundation.

Delpit, L. (2003). Educators as" seed people" growing a new future. Educational Researcher, 32(7), 14-21

Demaine, J. (2003). Social Reproduction and Educational Policy. International Studies in Sociology of Education, 13(2), 125-140.

Denhart, H. (2008). Deconstructing barriers perceptions of students labeled with learning disabilities in higher education. Journal of Learning Disabilities, 41(6), 483-497. 
Field, S., Sarver, M. D., \& Shaw, S. F. (2003). Self-Determination A Key to Success in Postsecondary Education for Students with Learning Disabilities.Remedial and Special Education, 24(6), 339-349.

Fitzgerald, T. (2004). Powerful voices and powerful stories: Reflections on the challenges and dynamics of intercultural research. Journal of Intercultural Studies, 25 (3), 233-245.

Frederickson, N. L., \& Furnham, A. F. (2001). The long-term stability of sociometric status classification: A longitudinal study of included pupils who have moderate learning difficulties and their mainstream peers. Journal of Child Psychology and Psychiatry, 42(5), 581-592.

Franklin, B. (1994). From "backwardness" to "at risk": Childhood learning difficulties and the contradictions of school reform. Albany, NY: SUNYPress.

Freire, Paulo (1994 [1970]). Pedagogy of the oppressed, $2^{\text {nd }}$ edition, New York: Continuum Publishing.

Gallegos, J., Langley, A., \& Villegas, D. (2012). Anxiety, Depression, and Coping Skills Among Mexican School Children A Comparison of Students With and Without Learning Disabilities. Learning Disability Quarterly, 35(1), 54-61.

George, P. (2013). The Research Process- A Journey and a destination [PowerPoint slides]. Retrieved from https://courses.ryerson.ca/webapps/portal/frameset.jsp?tab_tab_group_id= 15 1\&url=\%2Fw ebapps\%2Fblackboard\%2Fexecute\%2Flauncher\%3Ftype\%3DCourse\%26id\%3D_77431_1

Gil, L. A. (2007). Bridging the Transition Gap From High School to College Preparing Students With Disabilities for a Successful Postsecondary Experience. Teaching Exceptional Children, 40(2), 12-15.

Gibson, R. (1986). Critical Theory and Education. London: Hodder and Stoughton.

Giroux, H. (1983). Theory and Resistance in Education: A Pedagogy for the Opposition. Massachusetts: Bergin \& Garvey.

Giroux, H. \& McLaren, P. (1989). Critical pedagogy, the State, and Cultural Struggle. Albany: State University of New York Press.

Gould, S. J. (1981). The mismeasure of man. New York : W. W. Norton.

Groenewald, T. (2004). A Phenomenological Research Design Illustrated.International Journal of Qualitative Methods, 3, 1.Habermas, J. (1975). Legitimation Crisis. Boston: Beacon.

Hall, C. W., Spruill, K. L., \& Webster, R. E. (2002). Motivational and attitudinal factors in college students with and without learning disabilities. Learning Disability Quarterly, 7986.

Hargreaves, A., Margarida, F. \& Dinanthompson, M. (2003). Big Change Question Does Critical Theory Have any Practical Value for Educational Change?. Journal of educational change, 4(2), 181-188.

Hartman-Hall, H. M., \& Haaga, D. A. (2002). College students' willingness to seek help for their learning disabilities. Learning disability quarterly, 263-274. 
Heidegger, M. (1962). Being and time. J. Macquarrie \& E. Robinson (Trans.) San Francisco: Harper \& Row, Publisher, Inc.

Heiman, T., \& Precel, K. (2003). Students with Learning Disabilities in Higher Education Academic Strategies Profile. Journal of learning disabilities, 36(3), 248-258.

herising, Fairn, (2005). Interrupting positions: Critical thresholds and queer pro/positions. In L. Brown \& S. Strega (Eds.), Research as Resistance (pp. 127-152). Toronto: Canadian Scholars' Press.

Heydon, R., \& Iannacci, L. (2006). Biomedical approaches to literacy: Two curriculum teachers challenge the treatment of dis/ability in contemporary early literacy education. Language and Literacy, $7(2)$.

Hinshaw, S. (2007). The mark of shame: Stigma of mental illness and an agenda for change. Toronto: Oxford University Press.

Jones, N. \& Corrigan, P. W. (2014). Understanding Stigma. In Corrigan, P. W. (2014). (Ed.). The stigma of disease and disability: Understanding causes and overcoming injustices. Washington, D.C.: American Psychological Association, 9-25.

Kellner, D. (1989). Critical Theory, Marxism, and Modernity. Baltimore, MD: John Hopkins University Press.

Kellner, D. (2003). Toward a Critical Theory of Education*. Democracy \& Nature, 9(1), 51-64.

Kirby, D. (2011). Strategies for widening access in a quasi-market higher education environment: recent developments in Canada. Higher Education,62(3), 267-278.

Kistner, J., Haskett, M., White, K., \& Robbins, F. (1987). Perceived competence and self-worth of LD and normally achieving students. Learning Disability Quarterly, 37-44.

Kizzie, K. T. (2009). "It's Just a Disability" or Is It?: Stigma, Psychological Needs, and Educational Outcomes in African American Adolescents with Learning-Related Disabilities(Doctoral dissertation). Retrieved from Google Scholar.

Ladson-Billings, G. (1998). Just what is critical race theory and what's it doing in a nice field like education?. International Journal of Qualitative Studies in Education, 11(1), 7-24.

Learning disabilities: The hidden handicap. (1993, Feb). Today's Parent, 10, 18-20. Retrieved from http://ezproxy.lib.ryerson.ca/login?url=http://search.proquest.com/docview/232919061?a ccountid=13631

Learning Disabilities Association of Canada. (n.d.). A Working Description of Learning Disabilities. Retrieved from http://www.ldac-acta.ca/learn-more/ld-defined/a-workingdescription-of-learning-disabilities

Lee, H. (1999). Discussion paper for Oxfam: disability as a development issue and how to integrate a disability perspective into the SCO. Oxford: Oxfam.

Leichtentritt, J., \& Shechtman, Z. (2010). Children with and without learning disabilities: A comparison of processes and outcomes following group counseling. Journal of learning disabilities, 43(2), 169-179. 
Lester, S. (1999). An introduction to phenomenological research. Stan Lester Developments, 1-4.

Lightner, K. L., Kipps-Vaughan, D., Schulte, T., \& Trice, A. D. (2012). Reasons university students with a learning disability wait to seek disability services.AHEAD, 25(2), 145-159.

Linton, S. (1998) Disability studies/not disability studies, Disability and Society, 13(4), 525-540.

Madaus, J. W. (2008). Employment self-disclosure rates and rationales of university graduates with learning disabilities. Journal of learning disabilities,41(4), 291-299.

Martin, S. M. (2012). Education as a spectral technology: Corporate culture at work in Ontario's schools. Journal of Pedagogy/Pedagogický casopis, 3(2), 263-278.

McDonald, K. E., Keys, C. B., \& Balcazar, F. E. (2007). Disability, race/ethnicity and gender: themes of cultural oppression, acts of individual resistance. American Journal of Community Psychology, 39(1-2), 145-161.

McNulty, M. A. (2003). Dyslexia and the life course. Journal of Learning Disabilities, 36(4), 363-381.

Merleau-Ponty, M. (1996). Phenomenology of perception. C. Smith (Trans.). New York: Routledge. (First published 1962).

Miller, M. (2002). Resilience elements in students with learning disabilities.Journal of clinical psychology, 58(3), 291-298.

Mishna, F. (2003). Learning Disabilities and Bullying Double Jeopardy. Journal of learning disabilities, 36(4), 336-347.

Mok, K. (2005). Globalisation and Governance: Educational Policy Instruments and Regulatory Arrangements. Review of Education, 51, 289-311.

Morrow, R. A., \& Torres, C. A. (1994). Education and the reproduction of class, gender, and race: Responding to the postmodern challenge. Educational Theory, 44(1), 43-61.

Mullaly, B. (2010). Challenging oppression and confronting privilege, $2^{\text {nd }}$ edition. Toronto: Oxford University Press.

Oliver, M. (1990) The politics of disablement. London: Macmillan.

Pescosolido, B. A., Martin, J. K., Lang, A., \& Olafsdottir, S. (2008). Rethinking theoretical approaches to stigma: A Framework Integrating Normative Influences on Stigma (FINIS). Social Science \& Medicine, 67, 431-440.

Phelps, L. A., \& Hanley-Maxwell, C. (1997). School-to-work transitions for youth with disabilities: A review of outcomes and practices. Review of educational research, 67(2), 197-226.

Price, L. A., Wolensky, D., \& Mulligan, R. (2002). Self-determination in action in the classroom. Remedial and Special Education, 23(2), 109-115.

Prince, M. J. (2009). Absent Citizens: Disability Politics and Policy in Canada. Toronto: University of Toronto Press.

Poole et al. (2012). Sanism, 'mental health', and social work/education: A review and call to action. Intersectionalities, 1(1), 20-36. 
Potts, K. \& Brown, L. (2005), Becoming an anti-oppressive researcher. In L. Brown \& S. Strega (Eds.), Research as Resistance (pp. 255-286). Toronto: Canadian Scholars' Press

Reed, M. J., Lewis, T., \& Lund-Lucas, E. (2006). Access to post-secondary education and services for students with learning disabilities: Student, alumni and parent perspectives from two Ontario universities. Higher Education Perspectives, 2(2).

Reid, D. K., \& Valle, J. W. (2004). The Discursive Practice of Learning Disability Implications for Instruction and Parent-School Relations. Journal of Learning Disabilities, 37(6), 466-481.

Roer-Strier, D. (2002). University students with learning disabilities advocating for change. Disability \& Rehabilitation, 24(17), 914-924Rubin, A., \& Babbie, E. R. (2011). Research methods for social work ( $7^{\text {th }}$ ed.). Belmont, CA: Cengage Learning.

Rosen, A. (2006). Destigmatizing day-to-day practices: what developed countries can learn from developing countries. World Psychiatry, 5(1), 21.

Salutin, R. (2012). Keeping the public in the public education. Quebec: Linda Leith Publishing.

Samuels, E. (2002) Critical divides: Judith Butler's body theory and the question of disability, NSWA Journal, 14(3), 58-76.

Sattler, P. (2012). Education Governance Reform in Ontario: Neoliberalism in Context. Canadian Journal of Educational Administration and Policy.

Sever, M. (2012). A critical look at the theories of sociology of education.International Journal of Human Sciences, 9(1), 671-650.Shessel, I., \& Reiff, H. B. (1999). Experiences of adults with learning disabilities: Positive and negative impacts and outcomes. Learning Disability Quarterly, 22(4), 305-316.

Shakespeare, T. (2013). The social model of disability. In, L.D. Davis (2013) (Ed.). The Disability Studies Reader, Fourth Edition, New York: Routlege, 214-221.

Soyini Madison, D. (2005) Critical Ethnography: Method, Ethics and Performance. Thousand Oaks, CA: Sage

Strega, Susan. (2005). The view from the post-structural margins: Epistemology and methodology reconsidered, In L. Brown \& S. Strega (Eds.), Research as Resistance (pp. 199-236). Toronto: Canadian Scholars' Press.

Stubblefield, A. (2007). "Beyond the pale": Tainted whiteness, cognitive disability, and eugenic sterilization. Hypatia, 22(2), 162-181.

The Roeher Institute. (2000). Environmental scan: emerging issues in learning disability in Canada. Retrieved from http://www.pacfold.ca/download/Supplementary/EnvironmentalScan_08.pdf

Van Manen, M. (1984). Practicing phenomenological writing. UALibraries Site Administrator Test Journal 2, 2(1), 36-69.

Walker, L. (2001). Looking like what you are: sexual style, race and lesbian identity. New York: New York University Press. 
Watson, A. C., \& Larson, J. E. (2006). Personal responses to disability stigma: from self-stigma to empowerment. Rehabilitation Education, 20(4), 235-246.

Wilcke, M. M. (2002). Hermeneutic phenomenology as a research method in social work. Retrieved from http://www.ucalgary.ca/currents/files/currents/v1n1_wilcke.pdf

Wilcox, P., Winn, S., \& Fyvie-Gauld, M. (2005). 'It was nothing to do with the university, it was just the people': the role of social support in the first-year experience of higher education. Studies in higher education, 30(6), 707-722.

Wotherspoon, T. (1998). The sociology of education in Canada: Critical perspectives. Toronto, New York and Oxford: Oxford University Press. 